\title{
FY 1992 Measuments and Characterization Branch Annual Report
}

NREL/TP--412-5422

DE93 000094

P. C. Dippo, Editor

National Renewable Energy Laboratory 1617 Cole Boulevard Golden, Colorado 80401-3393

Operated by Midwest Rusearch Institute for the U.S. Department of Energy under Contract No. DE-AC02-83CH10093 


\section{NOTICE}

This report wass prepared as an account of work sponsored by an agency of the United States government. Neither the United States government nor any agency thereol!, nor any of their employees, makes any warranty, express or implied, or assumes any legal liability or responsibility for the accuracy, cumpleteness, or usefulness of any information, apparatus, product, or process disclosed, or represents that its use would not infringe privately owned rights. Reference hertin to any specific commercial product, process, or senvice by trade name, trademark, manufacturer, or otherwise does not necessarily constitute or imply its endorsement, recommendation, or favoring by the United States government or any agency thereof. The views and opinions of authors expressed heriein do not necessarily state or reflect those of the United States government or any agency thereof.

\section{Printed in the United States of America \\ Available from:}

National Technical Information Service

U.S. Department of Commerce

5285 Port Royal Road

Springfield, VA 22161

Price: Microfiche AO1

Printed Copy AOS

Codes are used for pricing all publications. The code is determined by the number of pages in the publication. Information pertaining to the pricing codes can be found in the current issue of the following publications which are generally available in most libraries: Energy Research Abstracts (ERA); Government Reports Announcements and Index (GRA and I); Scientific and Technical Abstract Reports (STAR); and publication NTIS-PR-360 available from NTIS at the above address. 


\section{TABLE OF CONTENTS}

INTRODUCTION ..................................... 1

Surface and Interface Analysis ..................... 1

Materials Characterization .............................. 1

Electro-Optical Characterization .................. 1

Cell and Module Performance ..................... 2

Materials Durability and Component

Reliability .........................................2

Surface Interactions, Modification, and

Stability ..............................................2

FTIR Spectroscopic and Research Center ....2

HIGHLIGHTS ................................................

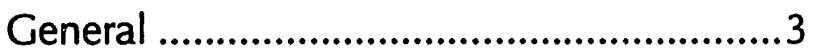

Surface and Interface Analysis ...................... 3

Materials Characterization ........................... 4

Electro-Optical Characterization ..................4

Photovoltaic Standards Activities .................5

Cell Performance ............................................5

Materials Durability and Component

Reliability ........................................6

Surface Interactions, Modification, and

Stability ............................................6

FTIR Spectroscopic Research Center .............7

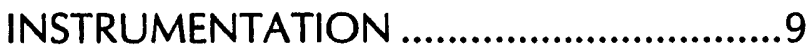

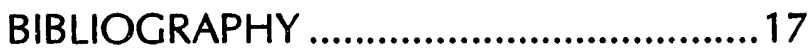

STAFF BIOGRAPHIES ............................23

COOPERATIVE LABORATORIES ...............25 


\section{INTRODUCTION}

The Measurements and Characterization Branch actively supports the advancement of DOE/NREL goals for the development and implementation of the solar photovoltaic (PV) technology. The primary focus of the laboratories is to provide state-of-the-art analytical capabilities for materials and device characterization and fabrication. The branch houses a comprehensive facility that is capable of providing information on the full range of $P V$ components. A major objective of the branch is to aggressively pursue collaborative research with other government laboratories, universities, and industrial firms for the advancement of PV technologies. Members of the branch disseminate research findings to the technical community in publications and presentations.

The Measuremer:ts and Characterization Branch encompasses seven coordinated research groups, providing integrated research and development that covers all aspects of photovoltaic materials/devices characterization.

\section{Surface and Interface Analysis}

\author{
A.J. Nelson, Senior Scientist and Group Leader \\ S.E. Asher, Senior Scientist \\ L.L. Kazmerski, Principal Scientist \\ H. Moutinho, Research Associate \\ D.W. Niles, Staff Scientist \\ R. Reedy, As ociate Scientist \\ A.B. Swartlander-Franz, Associate Scientist
}

The work of this group entails determinations of the chemical, compositional, and microelectricai characteristics of materials, surfaces, and device interfaces with extremely high depth and spatial resolution. Techniques include secondary ion mass spectrometry (SIMS); Auger electron spectroscopy (AES); scanning Auger microscopy (SAM); X-ray photoelectron spectroscopy (XPS); electron energy loss spectroscopy (EELS); electron-stimulated desorption spectroscopy (ESD); electron-beam-induced current and voltage (EBIC and EBIV); Auger voltage contrast (AVC); high-resolution elemental and ionic mapping, including volume-indexing; cooperative soft $\mathrm{X}$-ray synchrotron-source analysis; scanning tunneling microscopy (STM); and atomic force microscopy.

\section{Materials Characterization}

\author{
M.M. Al-Jassim, Senior Scientist and Group Leader \\ M.H. Bode, Staff Scientist \\ K.M. Jones, Staff Scientist \\ A.R. Mason, Master Technician \\ R.J. Matson, Staff Scientist \\ J. Zhu, Research Associate
}

This group employs advanced microscopy and microanalytical techniques in the determination of crystallographic, defect topographic, compositional, and microelectrical properties of PV materials and devices. These include electron probe microanalysis (EFMA) with energy-dispersive and wavelength-dispersive spectroscopy (EDS and WDS); scanning electron microscopy (SEM) to liquid helium temperatures; scanning transmission electron microscopy (TEM and STEM); voltage contrast; electronbeam-induced current and voltage characterization; electron diffraction; electron channeling; image analysis; $X$ ray diffraction; $\mathrm{X}$-ray fluorescence; microcathodoluminescence; cooperative high-resolution interface analysis using high-voltage electron microscopy; and complete sample preparation facilities, including ion etching with integral SIMS analysis.

\section{Electro-Optical Characterization}

\author{
R.K. Ahrenkiel, Principal Scientist and Group Leader \\ D.J. Dunlavy, Associate Scientist \\ B.M. Keyes, Associate Scientist \\ D.H. Levi, Staff Scientist \\ C.R. Osterwald, Staff Scientist \\ J. Zhang, P :search Associate
}

The work of this group involves determination of the electrical and optical properties of materiais and solar cells and laser spectroscopies, including photoluminescence and specialized determinations of minority-carrier properties. Capabilities and techniques include capacitance-voltage, conductance-voltage, and temperature dependencies; Hall effect/van der i fliv measurements; laser scanning; deep-level transient spectroscopy (DLTS): photoluminescence (PL); minority-carrier lifetime (to the picosecond range) and diffusion-length measurements; determination of minority-carrier mobility by time-offlight (TOF) measurements; picosecond laser spectroscopies; optical spectrophotometry; and ellipsometry. In addition, new facilities have been developed for the electrical characterization of high temperature superconducting materials. This includes measurements of resistance versus temperature ( $R$ vs. $T$ ), Meissner mutua! inductance (MMI), and critical current. 


\section{Cell and Module Performance}

\author{
K.A. Emery, Senior Scientist and Group Leader \\ E.E. Beck, Technician \\ H.R. Field, Staff Scientist \\ S. Rummel, Staff Scientist (PV Engineering and \\ Applications Branch)
}

The work of this group includes calibrating and maintaining primary PV reference cells; performing efficiency measurements under standard reporting conditions for single and multi-junction cells and modules; calibrating secondary reference cells for the PV community; and evaluating PV device parameters. Capabilities and techniques include; (1) Current-versus-voltage measurements as a function of temperature, spectral irradiance, and concentration; (2) Spectral response as a function of temperature, voltage bias, spectral irradiance, and concentration; (3) Laser photoresponse mapping; and (4) detection of measurement-related artifacts present in other current-versus-voltage measurement systems.

\section{Materials Durability and Component Reliability}

\author{
A.W. Czanderna, Research Fellow \\ G.C. Herdt, Resear \\ F.J. Pern, Senior Scientist \\ D.E. King, Staff Scientist
}

The work of this group involves the testing and reliability research of advanced PV submodules and modules, with primary emphasis on PV flat-plate modules. Specific project research activities include testing and investigation of submodule and module performance, stability, energy output, and reliability lifetime characteristics, both under simulated and actual sunlight conditions. These efforts are conducted in conjunction with PV research activities originating both with: and outside NREL. The group also coordinates PV thin-film module testing and reliability research for the US Department of Energy (DOE) Photovoltaic Program and develops simulated and outdoor testing methods and diagnostic techniques to understand and determine module performance and potential failure mechanisms.

\section{Surface Interactions, Modification, and Stability}

\author{
A.W. Czanderna, Research Fellow and Group Leader \\ G.C. Herdt, Research Associate \\ C.L. Fields, Visiting Professional \\ D.R. Jung, Research Associate \\ J.R. Pitts, Senior Srientist
}

The work of this group involves the fabrication, modification, and characterization of surfaces and interfaces to better understand their properties and structures. Capabilities include surface spectroscopies (ion scattering spectrometry (ISS), XPS, SIMS, fast atom bombardment $(F A B), A E S$, and SAM); Fourier transform infrared spectroscopy (FTIR); and contact-angle measurements, ultramicrogravity, and quartz crystal microbalance measurements. The group is able to perform reactions in the high-pressure chamber on the LHS-10 system, or in a solar furnace. In addition, the group has experience in the preparation and characterization of polymer films and organized molecular asser ablies (OMAs).

\section{FTIR Spectroscopic and Research Center}

\author{
J.D. Webb, Senior Scientist and Group Leader \\ D.E. King, Staff Scientist \\ E.). Johnson, Research Associate
}

This is a Laboratory-wide service center providing Fourier-transform infrared (FTIR) spectroscopic analysis and experimental design for determination of the covalent or lattice-bonding structure of materials, the effects of chemical reactions on materials, as well as the chemical composition and sub-ppm levels of impurities or dopants in samples. Techniques include: high-resolution, midinfrared FTIR spectroscopy in transmittance, specular reflectance, diffuse reflectance, and attenuated total reflectance (ATR) sampling modes using $5 \mathrm{~cm}^{2}, 0.5 \mathrm{~cm}^{2}$, and fiber optic ATR probes, along with environmental control for in-situ analysis and measurement of reaction kinetics for most sampling modes; FT-Raman and FTIRphotoluminescence spectroscopy in the reflective mode; and FTIR microscopy for obtaining mid-infrared transmittance or reflectance spectra of sample areas as small as $10 \times 10 \mu \mathrm{m}$, and far-infrared spectroscopy (650-50 $\mathrm{cm}^{-1}$ ) with transmittance and diffuse reflectance sample modes. 
HIGHLIGHTS

\section{General}

- R\&D 100 Award for the development of the Atomic Processing Microscope [APM].

- Three Branch members were honored with NREL Awards:

Brian Keyes, Outstanding Performance for "the operation of a facility which produces world class measurements characterizing semiconductor materials."

John Pern, Outstanding Achievement for "identifying the mechanisms of degradation in the ethylene vinyl acetate (EVA) copolymer used to encapsulate PV modules."

Roland Pitts, Outstanding Performance for "his work on solar induced surface transformation of materials using the solar furnace."

- More than 13,000 samples/devices/componentswere characterized during this past year. This included more than 46,000 measurements and tests in collaboration with some 100 organizations.

\section{Surface and Interface Analysis}

- Soft X-ray photoemission results on the $\mathrm{H}_{2} \mathrm{~S}$ gas and plasma-exposed surface of $n$-InP were used to correlate changes in the electronic structure to changes in the surface chemistry. These measurements indicated that the $\mathrm{H}_{2} \mathrm{~S}$ gas exposure and plasma exposure at glancing angles type-converts the p-type inP surface to an n-type surface and that the magnitude of the band bending is $0.6 \mathrm{eV}$, resulting in a homojunction interface. Additionally, for the initial $\mathrm{H}_{2} \mathrm{~S}$ exposures, the $\mathrm{S}$ bonds separately to both the in and the $P$, while at higher exposures a stable polymeric sulfur $\left(S_{n}\right)$ overlayer forms. This indicates that the formation of the P-S and In-S binary compounds is diffusion limited.

- An investigation on the effects of $\mathrm{H}_{2}$ plasma exposure of $\mathrm{CdS}$ using synchrotron radiation soft $\mathrm{X}$-ray photoemission and optical emission spectroscopy was completed. Plasma species were identified with optical emission spectroscopy, and revealed the presence of $\mathrm{Cd}_{2}$ and $\mathrm{S}_{2}$ species for the respective substrates. Photoemission results indicated that exposure to the $\mathrm{H}_{2}$ plasma preferentially removes the chalcogen component, thus creating chalcogen va- cancies in the surface region. Additionally, the surface type converts and proceeds from a flat-band condition to a surface exhibiting band bending. The observed presence of the chalcogen vacancies and the band bending at the surface show the usefulness of plasma processing for tailoring surface electronic properties of semiconductors.

- The formation and stability of the $\mathrm{CdS} / \mathrm{SnO}_{2}$ interface was investigated using $X$-ray photoemission. In.situ photoemission measurements were acquired after each $\mathrm{CdS}$ deposition on $\mathrm{SnO}_{2} /$ glass to observe the development of the interface. Results show that there is minimal chemical interaction or Sn outdiffusion between the two materials. Also, the valence band offset is estimated at $1.2 \mathrm{eV}<\Delta \mathrm{E}_{\mathrm{v}}<1.6 \mathrm{eV}$.

- A synchrotron radiation soft X-ray photoemission investigation on $\mathrm{ZnSe} / \mathrm{CulnSe} \mathrm{S}_{2}$ heterojunction formation was completed at the Alladin source, Synchrotron Radiation Center (SRC), University of Wisconsin-Madison. First-principles band structure calculations (S.-H. Wei and A. Zunger) show that $\mathrm{ZnSe} / \mathrm{CulnSe}$, has a significant valence band offset (VBO): $0.70 \pm 0.05 \mathrm{eV}$ for the relaxed interface and $0.60 \pm 0.05 \mathrm{eV}$ for the coherent interface. These large values demonstrate the failure of the "common anion rule." This is traced to a stronger $\mathrm{Cu}, \mathrm{d}-\mathrm{Se}, \mathrm{p}$ level repulsion in CulnSe ${ }_{2}$ than the $\mathrm{Zn}, \mathrm{d}-\mathrm{Se}, \mathrm{p}$ repulsion in $\mathrm{ZnSe}$. ZnSe overlayers were sequentially grown in steps on $p$ - and n-type CulnSe ${ }_{2}(112)$ crystals. RHEED analysis before and during growth indicated that the surfaces were ordered and that the ZnSe grows in registry with the substrate. In-situ photoemission measurements were acquired after each growth in order to observe changes in the valence band electronic structure as weil as changes in the $\ln 4 d$, Se $3 d$, and $\mathrm{Zn} 3 d$ core lines. Results of these measurements reveal that the $\mathrm{VBO}$ is $\Delta \mathrm{E}_{\mathrm{v}}=$ $0.70 \pm 0.15 \mathrm{eV}$, in good agreement with the firstprinciples prediction. This work marked the fifth year of the collaboration between researchers at SRC and A.J. Nelson, Group Leader of the Surface \& Interface Analysis Laboratory.

- A photoemission study of the $\mathrm{ZnTe} / \mathrm{CdTe}$ heterojunction was performed with an emphasis on valence band offsets as a function of strain relaxation. A valence band offset of zero for this heterojunction would yield an ohmic back contact for PV devices. Analysis of core-level spectra during interface formation demonstrated that the $\mathrm{ZnTe} /$ $\mathrm{CdTe}$ interface was abrupt and non-reactive. The valence band offset is strain dependent and measure- 
ments show that $\Delta E_{v}=-0.01 \mathrm{eV}$ for an unstrained interface and $\Delta E_{v}=0.13 \mathrm{eV}$ for a fully strained interface.

- The surface and bulk compositions of polycrystalline CulnSe $e_{2}$ thin films were determined for non-stoichiometric (non-stoichiometric means $\mathrm{Cu} / \mathrm{ln} \neq 1$ ) films by XPS. Results revealed that when $\mathrm{Cu} / \mathrm{ln}<1$, the bulk of the thin film is a mixture of $\mathrm{In}_{2} \mathrm{Se}_{3}$ and CulnSe ${ }_{2}$ with a skin of $\mathrm{Cu}_{1} / \mathrm{n}_{3} \mathrm{Se}_{5}$. Also, for $\mathrm{Cu} / \mathrm{In}>1$, a surface skin of excess Cu mixed with CulnSe ${ }_{2}$ was observed. The difference in the electronic structure of the surface versus the bulk of these films was further investigated using synchrotron-radiation-induced photoemission. The enhanced grain CulnSe ${ }_{2}$ films were sputter etched (500 V Ar) and analyzed in-situ to determine corelevel binding energies and Fermi level positions for the n-type Culn $\mathrm{Se}_{5}$ surface and the p-type CulnSe bulk within $\pm 0.1 \mathrm{eV}$. The transition between the n-type surface and the p-type bulk was experimentally observed by noting the change in the position of the valence band maximum (VBM) relative to the Fermi level $\left(E_{k}\right)$. From these measurements, the valence band offset $\left(\Delta \mathrm{E}_{\mathrm{v}}\right)$ between these two layers was determined to be $0.40 \mathrm{eV}$. Measurement of the work functions $(f)$ was also completed and reveals $\varphi=4.75 \mathrm{eV}$ for the Culn $\mathrm{Se}_{5}$ surface layer and $\varphi=$ $4.04 \mathrm{eV}$ for the bulk CulnSe ${ }_{2}$.

- A novel method for fabricating CdS on CdTe and for passivating surface and grain boundary defects in $\mathrm{CdTe}$ was developed using $\mathrm{H}_{2} \mathrm{~S}$ plasma modification of $\mathrm{CdTe}$ at elevated temperatures.

- $\quad \mathrm{CdS}_{x} \mathrm{Te}_{1-\mathrm{x}}$ and $\mathrm{ZnS}_{\mathrm{x}} \mathrm{Se}_{1-\mathrm{x}}$ alloys were fabricated using molecular beam epitaxial (MBE) growth of CdTe and $\mathrm{ZnSe}$, respectively, in an $\mathrm{ECR} \mathrm{H}_{2} \mathrm{~S}$ plasma. Substrate temperature, gas flow, and plasma power determine the film composition (XPS analysis) and growth rate.

\section{Materials Characterization}

- Initiated and maintained collaborative programs with the silicon industry (Texas Instruments ( $\mathrm{TI}$ ), Mobil Solar, Solarex, and Crystal Systems) to characterize defects in Si. Considerable progress has been made in characterizing TI's silicon spheres. This is leading to a CRADA between $\mathrm{TI}$ and NREL.

- Collaborated with Solar Cells, Inc., Golden Photon, Martin Marietta, the Institute of Energy Conversion, and the in-house $\mathrm{CdTe}$ program on the characteriza- tion of state-of-the-art CdTe thin-film solar cells. Transmission electron microscopy (TEM) was used to study the structural defects in these films, while SEM was used to investigate the electrical and luminescent properties of the material.

- Provided TEM characterization of hydrogen-related defects in hydrogenated polycrystalline Si.

- Collaborated with Kopin Corporation and Spire Corporation on the characterization of (GaAs/GalnP) and $(\mathrm{GaAs} / \mathrm{Si}, \ln \mathrm{P} / \mathrm{Si})$.

- New technique developments (for (a) a new EDX detector with an ultrathin Be window, allowing the detection of $\mathrm{C}$ and $\mathrm{O}$; and (b) an on-line image analysis system using a CCD array, which allows the recording, analysis, and storage of TEM images directly from the microscope in electronic form) have been acquired and implemented.

These new attachments were installed and tested. They have significantly enhanced our characterization capabilities.

- Business development: Collaborated with Ramtron Corporation on the characterization of lead zirconate titanate (PZT) ferroelectric thin films. This collaboration resulted in an outside funding of $\$ 86,000$ during 1992 and a significant improvement of Ramtron's dynamic memory devices.

\section{Electro-Optical Characterization}

- A specially designed low-temperature photoluminescence spectroscopy system was brought on-line. Using a variable temperature cryostat combined with the optical multichannel analyzer (OMA), PL data over sample temperatures from $2 \mathrm{~K}$ to $300 \mathrm{~K}$ can be provided on a rapid turn-around basis.

- A contactless minority-carrier lifetime measurement facility was developed for industry support of crystalline silicon.

- Time-resolved photoluminescence (TRPL) was successfully used to characterize the minority-carrier lifetime of polycrystalline CdTe provided by internal and external research groups. This NREL-developed technique is being used to provide the first accurate lifetime data for these polycrystalline semiconductors, and is assisting CdTe cell research and development groups for the optimization of their cells. 
- An identification of three oxygen complexes in $\mathrm{Al}_{\mathrm{x}} \mathrm{Ga}_{1-\mathrm{x}}$ As that are "lifetime-killer" defects was made in collaboration with the Research Triangle Institute.

- Time-resolved photoluminescence analysis of $n$ - and p-type InP wafers supplied by the Naval Research Laboratories (NRL) indicated that the lifetime in n-type wafers is orders of magnitude larger than in comparably doped $p$-type wafers. These results are typical of the contributions of this technique for the qualification of material for potential cell fabrication.

- Collaborative work with Purdue University found that lifetimes in epitaxial GaAs exceeded 1.0 microsecond by enhancing the photon recycling effect. This lifetime is 27 times greater than the radiative or theoretical lifetime.

\section{Photovoltaic Standards Activities}

- The Measurements and Characterization Program was asked to lead the international intercomparison for solar cells. Carl Osterwald was appointed chair of the PEP'93 International Intercomparison. The first organizational meeting was held in conjunction with the 11th European Photovoltaic Solar Energy Conference in Switzerland. These international PV measurement intercomparisons are conducted about every 5 years under the direction of the Photovoltaic Energy Project (PEP). This meeting, which was attended by representatives from major international PV laboratories, established the objectives, sample set, calibration methods, and schedule for the next intercomparison. The PEP '93 Intercomparison has been scheduled to begin in July, 1993, after a second participants' meeting that will be held during the 23rd IEEE PVSC in Louisville, Kentucky. Two separate sample sets will be circulated. The first will be composed entirely of $2 \times 2-\mathrm{cm}$ single-crystal Si reference cells that each participant will calibrate with their best calibration method. The results of these calibrations will be analyzed and used to establish the World PV Scale (WPVS) of primary reference cells. The second sample set will consist of devices from newer $P V$ technologies that have unique measurement problems, such as narrow band-gap cells, large-area cells, and series-connected tandem cells. Each participant is free to use whatever methods are appropriate to measure the second sample set.
- The first results from laboratories participating in the ASTM Cell and Module Intercomparison were received and are currently being processed. These results are expected to be reported at the 23rd IEEE. PVSC. Carl Osterwald chairs this activity.

- Revisions of ASTM draft PV standards for ASTM E44.09 (subcommittee on photovoltaics) were prepared. In conjunction with Heraeus DSET Labs, a revision of the solar weathering document was produced. This document is important to the U.S. PV program as it deals with determination of degradation of PV modules from UV exposure.

\section{Cell Performance}

- A new standardized outdoor I-V system for evaluating the wide variety of PV cells and modules under natural sunlight has been built. The system is designed to cover the current range from $\pm 10 \mu \mathrm{A}$ to $\pm 40 \mathrm{~A}$ and a voltage range from $\pm 0.001 \mathrm{~V}$ to \pm $100 \mathrm{~V}$. The system can bias in either direction and is designed to identify bias related artifacts. The system also measures the spectral irradiance, air temperature, sample temperature, wind speed, humidity, and direct and diffuse irradiance. In addition, the system is capable of biasing over a user-defined range.

- A new outdoor I-V system for comparing rating methods for crystalline and thin-film technologies has been completed and is currently performing data acquisition at NREL on crystalline $\mathrm{Si}, \mathrm{CIS}$, a-Si, and $\mathrm{CdTe}$ modules. The system can perform I-V measurements of 16 modules at 1 -minute intervals versus air temperature, sample temperature, wind speed, humidity, direct and diffuse irradiance, and spectra. The system was developed to allow the comparison of all the various module rating methods at the same site and time interval with all relevant $P V$ technologies.

- The large-area pulsed solar simulator (LAPSS) data acquisition system has been modified to handle high capacitance modules using a capacitive sweep circuit with varying sweep duration and the ability to measure the current at a fixed power supply voltage. The safety of the LAPSS system has been improved by incorporating a new HV cable with interlocks supplied by the manufacturer as a result of an informal suggestion during the Tiger Team visit. The high intensity lamp housing for the pulsed solar simulator has been installed. 
- The Spectrolab X25 continuous solar simulator, used for standardized single and multi-junction cell and submodule measurements and calibration, has been upgraded to accommodate $0.3 \mathrm{~m}^{2}$ single and multijunction modules.

- In support of internal research, subcontracted research, PV manufacturers, and the PV community, 1054 spectral response measurements, 1339 cell I-V calibrations, and 1931 module measurements were performed. These measurements/calibrations give the entire PV community a calibration traceability path to NREL. US manufacturers use this calibration traceability for their quality control programs.

\section{Materials Durability and Component Reliability}

- The broad-based applications potential has been elucidated for using fluorescence analysis (FA) to monitor or establish (1) the extent of ethylene vinyl acetate (EVA) discoloration and degradation in fielddeployed PV modules, (2) the extent of discoloration of other PV encapsulant polymers, (3) the relative number of residual chromophores in EVA at various stages of processing, and (4) an understanding of structural changes occurring within polymers that produce discoloration. The FA was also used to assist other researchers at NREL for solution-grown $\mathrm{CdS}$ thin films, porous $\mathrm{Si}$, and electrochromic samples.

- Degradation mechanisms of EVA encapsulant films have been identified via various acceleration experiments. The key thermal and photothermal EVA discoloration from polyene formation and color reversal by photobleaching are competing processes during the photothermal degradation process, and photobleaching of the discolored EVA can be effected by both the UV and visible light in the presence of air.

- The effects of EVA yellowing/browning on the I-V and efficiency of the solar cells were quantified in a degradation study of various EVA-encapsulated solar cells under accelerated thermal and photothermal conditions. The results further support previously established conclusions that UV exposure, elevated temperature, and hermetic enclosure are three major EVA-browning factors.

- The degradation mechanisms of PVB encapsulants in weathered PV modules are similar to those for $E V A$, as shown by FA and other techniques.
- Procedures were developed for polymer thin film sample preparation techniques, test methods, and numeric analysis, and experiments were conducted for developing and ranking new formulations and new encapsulation materials with various UV absorbers, anti-oxidants, and UV-absorbing glass superstrates.

- Development of procedures, techniques, and test methods for the diagnostic analysis of weather-degraded PV modules was continued (including nondestructive hot-spot infrared imaging, isolation of individual solar cells, resistances, and dark I- $V$ measurements of the isolated solar cells, and destructive EVA sampling and compositional analysis). The analysis was completed for a large number of degraded EVA films sampled from various modules made by several PV manufacturers. The results show that EVA degradation and discoloration result primarily from the loss of Cyasorb UV 531 and the formation of long conjugated $C=C$ bonds due to loss of acetate pendant groups.

- Studies were initiated on the formation mechanisms of $\mathrm{SnO}_{2} / \mathrm{CdS}$ interfaces and their stability in real environments. Modules that were degraded by water vapor have been acquired for analysis by surface analysis techniques.

- The purchase, installation, and testing were completed for three light sources, including a DSET Suntest CPS table-top exposure system, an Oriel 1-kW Xe arc lamp light source, and an Oriel 1-kW Xe arc lamp UVenhanced solar simulator, resulting in a greatly improved capability and capacity of performing accelerated photodegradation experiments. The purchase, installation, and testing were completed for the hardware, computer system, and software of an HP Model 1090/M high performance liquid chromatograph (HPLC) and a SPEX Model FL11 2 fluorescence spectrophotometer.

- Practical suggestions were made to staff members of several PV manufacturers for improving the current EVA formulations and processing conditions, on the basis of NREL accumulated experimental results and observations.

\section{Surface Interactions, Modification, and Stability}

- A number of experiments in rapid thermal processing at the NREL High Flux Solar Furnace were carried out. These included processing of ceramic super- 
conductors, the growth of diamond-like carbon films, metallization and joining of engineered ceramic materials, and cladding of cermet powders to stainless steel.

- NREL CRADA\#5 was initiated with Brush Wellman, Inc., in June, 1992. Work has proceeded on schedule for new metiiods of metallizing and bonding engineered ceramic materials. Negotiations for extending the CRADA into a second phase of development are underway. Contributions were made to the development of the Coors CRADA and planning of experiments to elucidate the growth mechanism of $\mathrm{SiC}$ on $\mathrm{SiO}_{2}$ surfaces in the high-flux solar environment.

- Patent disclosures were filed on three promising technologies. The applications are in various stages of preparation: "Rapid Thermal Metalorganic Deposition of Metal and Oxide Thin Films," NREL IR\#9210, DOE Case No. S-75,895; "Solar-Induced Chemical Vapor Deposition (CVD) of Diamond-Type Carbon Films," NREL IR\#92-27; and "Modification of Aerodynamic Surfaces to Minimize Soil Retention," NREL IR\#92-22.

- In studies of copper deposited onto the organic functional end group of organized molecular assemblies (OMAs), we used XPS to show that $\mathrm{Cu}$ interacts with the $\mathrm{OH}$ groups of 11-mercaptoundecanol for coverages below $0.5 \mathrm{~nm}$. At higher coverages, copper penetrates the OMA and reaches the OMA $\mathrm{Au}$ interface. For $\mathrm{Cu}$ deposited onto OMAs with a $\mathrm{CN}$ end group, weak interactions occur below $0.1 \mathrm{~nm}$; then further deposition of copper resides primarily at the OMAAu interface.

- A critical review of research needs and opportunities in surface processing was completed and addresses 10 topical areas of applied surface science. Six of the topical areas (i.e., corrosion, polymer/metal (oxide) interfaces, thin-film multilayer solar collectors, accelerated life testing, interfacial microchemical characterization, and organized molecular assemblies) are directly relevant to PV devices. The other topics covered were fuel cells and solid batteries, lubrication and wear surfaces, photoelectrochemistry, and conducting polymers.

- The proceedings of a surface processing workshop were edited, published as an NREL document [24], and accepted for publication in Critical Reviews in Surface Chemistry. The 440-page NREL document contains current status summaries of methods of surface characterization, surface modification, and the recommendations of research needs and opportunities in 10 topical areas of applied surface science (see previous bullet).

- An invention disclosure was made for using OMAs on high surface area materials as selective molecular getters.

- A collaborative study is now in progress with the University of Denver using their 0-Atom Beam Facility to expose surfaces for XPS, FTIR, and ISS analysis at NREL. Initial results have been obtained after exposing Ag films to the ground-state, ca. $5-\mathrm{eV}, 0$ atom source and for several silicone polymers.

- The adsorption of toluene and trichloroethylene (TCE) and the competitive adsorption of water on several different polymers has been investigated using beam microbalance techniques. Polycarbonate coated onto high-area silica gels is the best polymer of those used for adsorbing TCE.

\section{FTIR Spectroscopic Research Center}

- Roorn-temperature photoluminescence $(\mathrm{PL})$ spectra were obtained from crystalline $\mathrm{Si}, \mathrm{GeGaAs}, \mathrm{CulnSe}_{2^{\prime}}$ and GaInAsP using the Nicolet 800 FTIR spectrophotometer with an FT-Raman accessory. This new measurement technique enhances our capability to measure PL in the infrared, and will enable sensitive, convenient characterization of these materials.

- We contributed to a detailed study of differences in hydrogen evolution rate from annealed, hydrogenated amorphous silicon samples prepared using different deposition methods. The results contributed to better understanding of structural differences between these materials.

- Under our work-for-others contract with NASA through SAIC, we published a paper describing the interactions between contaminants in the composite materials used to prepare solid rocket motors. 


\section{INSTRUMENTATION}

\section{SURFACE AND INTERFACE ANALYSIS LABORATORY}

\section{Instrument}

XPS/Auger System (Perkin Elmer PHI 550)

Scanning Auger Microprobe (Perkin-Elmer PHI 590)

\section{Scanning Auger Microprobe} (Perkin-Elmer PHI 600)

Ion Microprobes

(Cameca IMS-3f)

Scanning Tunneling Microscope (RHK 100 and MCAllister)

Atomic Processing Microscope (APM)

Scanning Tunneling Microscope/ Atomic Force Microscope

(Park Scientific)

Scanning Force Microscope (Park Scientific AutoProbe)

\section{Range/Capacity}

2-mm spot size detection sensitivity of 0.1 at. $\%$ Li to $U, 1-\mathrm{cm}^{2}$ sample size

$0.1-\mu \mathrm{m}$ spot size, SAM detection sensitivity of 0.1 at. \% for $\mathrm{Li}$ to $U$, SIMS detection of $1 \mathrm{ppm}$ for $\mathrm{H}$ to $U, 1-\mathrm{cm}^{2}$ sample size

$0.02-\mu \mathrm{m}$ spot size, same detection sensitivities as for $\mathrm{PHI} 5901-\mathrm{cm}^{2}$ sample size

10-200- $\mu \mathrm{m}$ beam spot: Cs, O, or Ar primary ions; all elements and isotopes, $\mathrm{H}-U$, sensitivities of 1 ppm-1 ppb: $1-\mathrm{cm}^{2}$ sample size

Atomic-level spatial resolution

Atomic-level spatial resolution; spectroscopic imaging

Atomic-level spatial resolution

Contact and non-contact imaging on nanometer scale

\section{Unique Features and Uses}

Performs AES, XPS, UPS, EELS in conjunction with depth profiling quantitative elemental analysis and chemical bonding information, angle resolved photoemission.

Performs SAM and SIMS analysis with depth profiling, quantitative elemental analysis, and surface compositional maps, up to $(5000 \mathrm{X}$ micrographs of surface features).

Performs SAMS and SIMS analysis with depth profiling quantitative elemental analysis and surface compositional maps, (up to $50,000 \times$ micrographs of surface features). Hot/cold stage.

Performs high-sensitivity profiling and mass scans with 10-nm depth resolution; mass resolution $(M \Delta / M)=10,000$ lateral ion imaging resolution of $1 \mu \mathrm{m}$.

Nanometer through atomic level imaging of conducting samples; light bias for higher resistivity semiconductors; ultrahigh vacuum chamber; sample and tip exchange.

STM capabilities for spectroscopic imaging; atomic and nanoscale processing, including single-atom manipulation; nanoscale characterization.

Ultrahigh vacuum STM and AFM capabilities.

Air-operated atomic force microscope for the nanoscale characterization of non-conducting surfaces, including biological samples. 
MATERIALS CHARACTERIZATION GROUP

Instrument

Electron probe $X$-ray microanalyzer (EPMA) Cameca-MBX

SEM JEOL JSM-35C

SEM JEOL JSM-840

TEM Philips CM - 30

\section{Range/Capacity}

EDS and WDS analysis of an accuracy of $\pm 0.5 \%$

1-49-kV, secondary electron imaging (SEI) 5-nm resolution backscattered electronic imaging (BEI) 9-nm resolution
0.2-40-kV, liquid -helium catholdoluminescence (CL) cold stage. Integrated and spectral $\mathrm{CL}$ from $10^{\circ} \mathrm{C}$ to $\mathrm{RT}^{\circ}$, from $300 \mathrm{~nm}$ to $1.8 \mu \mathrm{m}$

KeV: 300 , resolution: $2.3 \dot{A}$, Tilt: $\pm 60^{\circ}$

\section{Unique Features and Uses}

Quantitative compositional arralysis of all elements heavier than boron.

EDS: compositional analysis $(>\mathrm{Na})$; EC: Crystalline type orientation and quality; EBIC: Microcharacterization of the electrical activity of electronic materials, junction location, and diffusion length measurement.

Characterize -olative impurity concentrations, defect densities and distributions, bandgap (Eg), and sus-bandgap (defect) luminescence with high resolution and correlation with topography.

Performs structural, analytical, and high resolution examination of a wide range of materials.

\section{ELECTRO-OPTICAL CHARACTERIZATION LABORATORY}

\section{Instrument}

Photoluminescence Spectroscopy System

Photoluminescence Lifetime System

Diffusion Time-of-Flight System

Superconductivity Test Station

Deep Level Transient Spectroscopy (DLTS)

\section{Range/Capacity}

$\mathrm{CW}$ and cavity-dumped $(40 \mathrm{kHz}$ to $40 \mathrm{MHz}$ ) excitation sources, detection capability from 400 to $1,700 \mathrm{~nm}$, sample temperature range of 4 to $310 \mathrm{~K}$

Cavity-dumped ( $40 \mathrm{Khz}$ to $40 \mathrm{MHz}$ ) excitation, detection capability from 700 to $1,700 \mathrm{~nm}, 50$-ps time resolution, sample temperature range of 4 to $310 \mathrm{~K}$

Cavity-dumped ( $40 \mathrm{kHz}$ to $40 \mathrm{MHz}$ ) excitation, detection capability from 700 to $1,700 \mathrm{~nm}, 45$-ps time resolution

65-300 K, 3.2-22.0 $\mu \dot{A}, 1-10 \vee$ rms

DLTS spectra and transients from 77 to $320 \mathrm{~K}$

\section{Unique Features and Uses}

Energy-resolved photoluminescence spectroscopy.

Time-resolved photoluminescence spectroscopy for minority carrier lifetime and surface recombination measurements.

Minority-carrier diffusion, lifetime, and surface recombination measurements.

$T_{c}$ measurement of superconducting materials.

Determination of trap ionization energies, emission rates, and capture cross-sections. 
Capacitance-Voltage Measurement System

\section{Instrument}

Spectrolab X25

(With Multisource Attachment)

Current vs Voltage (I-V)

Measurement System

Spectral Response Measurement System

Spectrolab Large Area Pulsed

Solar Simulator (LAPSS)

Spectrolab Pulsed Concentrator Solar Simulator

PV Calibration System

PV Rating Analysis System

LICOR Spectroradiometer
Capacitance as a function of voltage over the frequency range $100 \mathrm{~Hz}$ to $100 \mathrm{MHz}$
Determination of the effective doping concentration.

\section{CELL AND MODULE PERFORMANCE GROUP}

\section{Range/Capacity}

$100 \mathrm{Wm}^{-2}$ to $20,000 \mathrm{Wm}^{-2}$, usercontrolled spectral and total irradiance $33 \times 33 \mathrm{~cm}^{2}$ beam

\pm 50 to $\pm 1 \mu \mathrm{V}, \pm 8$ A to $\pm 1 \mathrm{pA}, 0^{\circ} \mathrm{C}$ to $110^{\circ} \mathrm{C}$, voltage bias rates from steady state to $200 \mathrm{~V} / \mathrm{sec}$

$300-2,000 \mathrm{~nm}$ expandable to $10,000 \mathrm{~nm}$, light bias to -5 suns, voltage bias to $\pm 40 \mathrm{~V}$, current range $1 \mathrm{pA}$ to $4 \mathrm{~A}$, up to $100 \mathrm{~cm}$ diameter monochromatic beam

$2 \times 2-\mathrm{m}$ area at $1000 \mathrm{Wni}^{-2}$, $\pm 100 \mu \mathrm{A}$ to $\pm 13 \mathrm{~A}$ full-scale current, $\pm 1 \mathrm{~V}$ to $\pm 70 \mathrm{~V}$ voltage range, custom data acquisition system

$10 \times 20-\mathrm{cm}$ area at 1 to 2000 suns, $\pm 100 \mu$ A to \pm 13 A full-scale current, $\pm 1 \mathrm{~V}$ to $\pm 80 \mathrm{~V}$ voltage range, 1-msec pulse

Two Newtonian trackers, four samples at a time biased to $I_{\mathbf{s c}}$, temperature control and monitoring 40 samples at a time if $\mathrm{I}_{\mathrm{sc}}$ and total irradiance measured separately and under global sunlight

I-V of 16 modules at 1 -min intervals vs air temperature, sample temperature, wind speed, humidity, direct and diffuse irradiance, and spectra

300-1,100 nm, 4-nm resolution, global light (integrating sphere), direct normal light $\left(5.0^{\circ}\right.$ field of view), Teflon dome diffuser, fiber optic probe. Computer model extension of outdoor spectra to $300-4000 \mathrm{~nm}$

\section{Unique Features and Uses}

Solar simulation under standard or user-defined reporting conditions.

Efficiency measurements, secondary reference cell calibration, temperature coefficients, diode parameters, dark I-V, I-V measurement artifacts.

Quantum efficiency, device parameters. Capable of measuring modules or small cells.

Module measurements, detect and correct I-V artifacts related to a pulsed light source's large bias rate.

Concentrator I-V measurements, correct bias rate, temperature, and spectral artifacts.

Primary calibration of solar cells under direct or global sunlight; or modules under global light (fixedtilt or normal incidence).

Compare all of the various module rating methods at the same site and time interval with all relevant PV technologies.

Required for efficiency measurements and calibrations, simulator spectral characterization. 
GER Spectroradiometer

HP1000 Computer and Macintosh

Computers

Standardized Outdoor I-V System

Spire Solar Simulator
300 to $1100 \mathrm{~nm}, 4-\mathrm{nm}$ resolution global light (integrating sphere, diffusing plate), direct normal light $\left(5.0^{\circ}\right.$ field of view)

I-V of cells and modules, $\pm 10 \mu \mathrm{A}$ to $\pm 40 \mathrm{~A}, \pm 0.001 \mathrm{~V}$ to $\pm 100 \mathrm{~V}$ with air temperature, sample temperature, wind speed, humidity, direct and diffuse irradiance, spectra, and data base

$\mathrm{I}-\mathrm{V}$ measurements on modules and cells $0.1 \mathrm{~mA}$ to $20 \mathrm{~A}$, $0-70 \mathrm{~V}$
Required for efficiency measurements and calibrations, simulator spectral characterization.

Control of measurement systems; data base management.

Flexibility to evaluate any PV cell or module at one sun or under concentration. Designed to evaluate bias related artifacts.

High throughput module measurements.

\section{SURFACE INTERACTIONS, MODIFICATIONS AND STABILITY GROUP}

\section{Instrument}

\section{XPS/ISS/SIMS FAB SIMS/AES}

(Leybold LHS-10 System)

Scanning Auger Microprobe (Physical Electronics 545C)

Quartz Crystal Microbalance System (Sycon-NREL)

\section{Range/Capacity}

XPS: 2 to $10-\mathrm{mm}$ area; ISS; 0.5 to $2-\mathrm{mm}$ spot size; SIMS: 0.5 to 2-mm spot size; AES: 1- $\mu \mathrm{m}$ spot size. Detection sensitivities of 0.1 to 1 at. \% for XPS, AES, and ISS; of ca. $10^{-4}$ at. $\%$ for SIMS

3.0- $\mu \mathrm{m}$ minimum size for electron beam; detection sensitivity of 0.1 to 1.0 at. $\%$ for $\mathrm{Li}$ to $U$

Range of $10^{6} \mathrm{ng} / \mathrm{cm}^{2}$; detection sensitivity of $1 \mathrm{ng} / \mathrm{cm}^{2}$; practical capacity for hydrophilic polymers is about $1.5 \mathrm{mg}$; for other solids, $100 \mathrm{mg}$; $\mathrm{T}$ from 15 to $75^{\circ} \mathrm{C}$;

$P$ from vacuum to 1,500 torr

Capacity of 3 to $5 \mathrm{~g}$; detection sensibility of 0.1 to $1 \mu \mathrm{g}$; measuring range of $400 \mathrm{mg}$; $T$ from $-196^{\circ}$ to $1,000^{\circ} \mathrm{C}$. P from vacuum to 1,500 torr
Unique Features and Uses

Depth profiling with a $1-\mathrm{mm} \leq$ 1-cm raster range. Thin-film deposition with QC monitor in a preparation chamber; translation of sample on heatable (to $800^{\circ} \mathrm{C}$ ) coolable (to $-196^{\circ} \mathrm{C}$ ) rods from preparation or high pressure chambers (to $10 \mathrm{~atm}$ ) into the analysis chamber; four different surface analysis probes on one instrument; $F A B$ source for $F A B$ SIMS.

AES or SAM analysis while depth profiling; rapid-load lock and multiple sample carousel permits high throughput for routine analyses.

Measure adsorption/desorption of gases on solid overlayers adherent to a gold-coated quartz crystal; mass gain or loss during oxidation or reduction; permeation rates of gases through solids up to $100-\mu \mathrm{m}$ thick; especially good for water vapor sorption studies.

Same applications as QCM. Samples (suspended by fibers) can be monitored for outgassing and desorption with an RGA. 
Deposit Thickness Monitor

(Inficon IC-6000)

Metallograph

(LECO Neophot 21)

Solar Furnace

(NREL)

Profilometers

(Tencor Alpha-Step and

Sloan Dektak)

Oriel Model 6732 Solar Simulator

Lambda-Physik EMG-50 Excimer

Laser and FL-2000 Dye Laser

Polaron Series E6000 Vacuum Coater
Measure deposition rates

$0.05 \mathrm{~nm} / \mathrm{min}$ to over $10 \mathrm{~nm} / \mathrm{s}$

and deposited thicknesses to

$10,000 \mathrm{~nm}$ to less than $1 \%$ accuracy

Mag: $80 \mathrm{X}$ to $2,000 \mathrm{X}$ polarization

quantinet 800 image analysis

10-kW maximum flux, $250 \mathrm{~W} / \mathrm{cm}$, $40 \mathrm{~mm}$ FWHM

Measurement range from $100-\mathrm{nm}$ full scale to $100-\mu \mathrm{m}$ full scale

Unfiltered spectral output from 0.25 to $2.5 \mu \mathrm{m}$ at about 17 solar constants (collimated $5-\mathrm{cm}^{2}$ output beam).

Monochromatic, coherent output, with wavelengths variable between $197-950 \mathrm{~nm}\left(1-\mathrm{cm}^{2}\right.$ output beam)

$10^{-7}$ torr vacuum capability, sputter or evaporative coating
Monitor vacuum-deposited overlayer thicknesses in the LHS -10 preparation chamber for preparing clean metal deposits and subsequent XPS/ISS/SIMS/ AES analysis without exposure to air.

Optical microscopy with or without polarized light, Nomarski, prints/ slides, and image analysis.

Long focal length in primary concentrators (7.05 m); capable of inserting secondary concentrator to boost flux to the range of $5000 \mathrm{~W} / \mathrm{cm}^{2}$; fully automated operation and data acquisition.

Measures step heights and surface topography with \pm 1 -nm sensitivity; auto-level, microscope $X-Y$ translation stage for sample positioning $12.5-\mu \mathrm{m}$ and $5-\mu \mathrm{m}$ diameter tips available.

Equipped with filters and dichroic reflectors to limit spectral output to a desired range for photochemical studies.

Complements the solar simulator in photochemical studies; excimer is currently set up for 308-nm output, and dye laser is now tuneable between 260 and $320 \mathrm{~nm}$.

Used to deposit thin films (usually of metals) onto smooth substrates; typical use is to prepare IRreflective, metal-coated substrates for IR-external-reflection spectroscopy.

\section{FTIR SPECTROSCOPIC RESEARCH AND SERVICE CENTER}

\section{Instrument}

Nicolet System 800 High Resolution Mid-Infrared FTIR Spectrophotometer

Nicolet FT-Raman Accessory

\section{Range/Capacity}

Frequency range 7,800 to $500 \mathrm{~cm}^{-1}$, resolution $0.1 \mathrm{~cm}^{-1}$, sensitivity $10^{-5}$ O.D.

Frequency range $3,800-150 \mathrm{~cm}^{-1}$ Stokes

\section{Unique Features and Uses}

Collects high-resolution, low-noise, mid-infrared spectra of solid and liquid samples in transmittance, specular and diffuse reflectance, and attenuated total reflection modes; also used with FT-Raman accessory.

Collects Raman and photoluminescence spectra of solid and liquid samples. 
Nicolet Nic-Plan FTIR Microscope

Nicolet System 710 MediumResolution Mid-infrared FTIR Spectrophotometer

Nicolet System 20F Medium Resolution Far-infrared FTIR Spectrophotometer

Hansen High-TranCryostatic Sample Mount

Nicolet 7199b High-Resolution Mid-Infrared FTIR Spectrophotometer
Minimum sample size $10 \times 10 \mu \mathrm{m}$, translational resolution $1 \mu \mathrm{m}$, includes automated scanning stage and color micrography

Frequncy range 7,000 to $400 \mathrm{~cm}^{-1}$ (standard samples), 7,800-650 $\mathrm{cm}^{-1}$ (FTIR microscope), resolution 1.0 $\mathrm{cm}^{-1}$

Frequency range $650-20 \mathrm{~cm}^{-1}$, resolution $0.7 \mathrm{~cm}^{-1}$, evacuable optics

Sample temperature control range $8.0-450 \mathrm{~K}$

Frequency range, $7800-500 \mathrm{~cm}^{-1}$, expandable to $25,000-100 \mathrm{~cm}^{-1}$, resolution $0.06 \mathrm{~cm}^{-1}$, sensitivity 10-5 O.D.
Collects mid-infrared spectra of small-area solid samples in reflectance and transmittance modes; used with System 710.

Primarily used with FTIR microscope, but has sample compartment for mid-infrared träismittance analysis.

Collects far-infrared spectra of solid samples in transmittance and diffuse reflectance modes.

Provides temperature and illumination control for solid samples during infrared transmittance analysis in vacuo; used with Systems $20 \mathrm{~F}$ and 800.

Coliects high resolution, low-noise, mid-infrared spectra of solid and liquid samples in transmittance, specular reflectance, and attenuated total reflection modes.

\section{MATERIALS DURABILITY AND COMPONENT RELIABILITY RESEARCH}

\section{Instrument}

Denver Instrument A200DS

Electronic Analytical Balance

DSET Suntest CPS System with a Black Panel Thermometer

Oriel Model 81281 UV-ehanced Solar Simulator with a Power Supply (Model 68820)

Oriel Photofeedback

Controller (Model 68850)

Oriel 100 W Xe Arc Lamp/Lamp Housing (Model 66021)

Oriel Power Supply (Model

66820)

Oriel Ozone Eater

(Model 66087)

\section{Range/Capacity}

$0.1-\mathrm{mg}$ and $0.01-\mathrm{mg}$ resolution

$1500-W$ Xe burner, $(20-\mathrm{cm} \times 28-\mathrm{cm})$ sample plate (removeable), and programmable timer

1000-W Xe lamp (reduced IR intensity)

Can hold a 450 to $1000-\mathrm{W}$ Xe or $\mathrm{Xe}(\mathrm{Hg})$ lamp

400 to $1000 \mathrm{~W}$

Activated carbon fibers

\section{Unique Features and Uses}

Accurate weights measurement.

Tabletop exposure unit; easy operation for small and large samples.

For accelerated tests for UV degradation of polymer materials and mini-modules.

Light intensity auto-feedback controller for solar simulator.

For photochemistry and other applications that require intense light.

Power supply for the 1000-W Xe lamp.

Portable unit, useful for filtering ozone produced from $1000-\mathrm{W}$ Xe arc lamp. 
Sunlighter RS/4 Test System

(Model 15)

\section{HP-8452A UV-visible}

Spectrophotometer

M.-M. Micromanipulator

(Model 6000)

Lab-line Duo-Vac ovens (Three

units), Two Mini-Vac Pumps

Orion pH Meter, Model 720A (With an Electrode Switch)

Fluke 8050A Digital Multimeter

Keithley 485 Autoranging

Picoammeter

Cole-Parmer 4658 and WWR

Scientific 370 Stirrer/Hot Plate

Omega Digital Thermometers (3)

Branson Model 3200 Ultrasonic

Cleaner

GraLab 900 Programmable

Electronic Timer
3 GE RS/4 UV lamps with a

turntable

$190 \mathrm{nrn}$ to $820 \mathrm{~nm}, 2-\mathrm{nm}$

resolution

Optical microscope, XYZ-transportable platform with four needle probes

$25^{\circ} \mathrm{C}$ to $260^{\circ} \mathrm{C}$

$\mathrm{pH} 0$ to 14 and ion-selective analysis

AC/DC, MA, V, Ohms

Digital reading $\left(0.1^{\circ} \mathrm{C}\right)$
Temperature measurement.

Ultrasonic cleaning.

Test chamber for accelerated testing of materials.

Absorption and transmission measurements.

For microscopic examination and/or resistance measurement of small objects.

General purpose heating or drying.

$\mathrm{pH}$ measurement for aqueous solutions; useful for analysis of metal cations or anions.

For current, voltage, and resistance measurement.

Nano- to picoamper measurement.

Stirring and heating.

Timer. 


\section{BIBLIOGRAPHY}

1. Abou-Elfotouh, F.; Ahsour, S.; Alkuhaimi, S.; and Matson, R.; "The Formation and Junction Behavior of the Polycrystailine CdTe interface with CdS and Metal Contact Thin Solid Films", (in press), 1993.

2. Abou-Elfotouh, F.; Ashour, S.; Alkuhaimi, S.A.; Zhang, J.; Dunlavy, D.J.; and Kazmerski, L.L.; "The Study of Defect Levels and Interface Properties of CdTe and CdS Polycrystalline Thin Films", Proc. Mat. Res. Soc. Symp., Vol. 238, pp. 335, 1992.

3. Abou-Elfotouh, F.A.; and Coutts, T.J.; "rf Planar Magnetron Sputtering of Polycrystalline CdTe Thin Film Solar Cells", International Journal on Solar Energy, Special Issue on CáTe Solar Cells, 1992.

4. Ahmad-Bitar, R.; Moutinho, H.; Ahrenkiel, R.; Abou-Elfotouh, F.; Dunlavy, D.; Keyes, B.; Matson, R.; Mason, A.; and Kazmerski, L.; "Study of the Process Treatments Used for HighEfficiency Thin-Film CdTe/CdS Solar Cells", Proc. 10th European Communities Photovoltaic Energy Conference, Montreaux, Switzerland, (Kluwer Academic Publishers, The Netherlands), 1992.

5. Ahrenkiel, R.K.; Keyes, B.M.; Dunlavy, D.J.; and Kazmerski, L.L.; "Improvement of Device Efficiency by Time-Resolved Photoluminescence Measurements", Proc. 10th European Communities Photovoltaic Energy Conference, Montreaux, Switzerland, (Kluwer Academic Publishers, The Netherlands), pp.533-536, 1992.

6. Ahrenkiel, R.K.; “Measurement of Minority-Carrier Lifetime by Time-Resolved Photoluminescence", Solid State Electronics, 35, pp. 239, 1992.

7. Ahrenkiel, R.K.; Keyes, B.M.; Lush, G.B.; Melloch,M.R.; Lundstrom, M.S.; and MacMillan, H.F.; "Minority-Carrier Lifetime and Photon Recycling in n-GaAs", J. Vac. Sci. Technol., A10, pp. 990, 1992.

8. Ahrenkiel, R.K.; Keyes, B.M.; Wang, L.; and Albright, S.P.; "Minority-Carrier Lifetime of Polycrystalline CdTe in CdS/CdTe Solar Cells", Proc. 22nd IEEE Photovoltaic Specialists Conference, pp. 940, 1991.

9. Ahrenkiel, R.K., Ed., "Properties of AlGaAs", INSPEC 1993, (Datareviews on minority-carrier lifetime, diffusivity), The Institution of Electrical Engineers, UK (in press), 1993.

10. Ahrenkiel, R.K., Editor, "Properties of InP", INSPEC 1991 (Datareviews on minority- carrier lifetime, diffusivity), The Institution of Electrical Engineers, UK, 1992.

11. Ahrenkiel, R.K., Guest Editor, Semiconductors and Semimetals, on Minority Carrier Properties of III-V Semiconductors, Academic Press, 1993.

12. Al-Jassim, M.M.; Jones, K.M.; Ahrenkiel, S.P.; Keyes, B.M.; Vernon, S.M.; and Karam, N.H.; "TEM and PL Characterization of GaAs and $\mathrm{ZnSe} / \mathrm{ZnCdSe}$ Grown on Si", Proc. Solid State Devices and Materials Conf., Tsukuba, Japan, August 26-28, 1992.

13. Albin, D.; Carapella, J.; Gabor, A.; Tennant, A.; Tuttle, 1.; Duda, A.; Matson, R.; Mason, A.; Contreras, M.; and Noufi, R.; "Fundamental Thermodynamics and Experiments in Fabricating High Efficiency CulnSe ${ }_{2}$ Solar Cells by Selenization Without the Use of $\mathrm{H}_{2} \mathrm{Se}^{\prime \prime}$, Proc. 11 PV AR\&D Meeting, Golden, CO, May, 1992.

14. Arent, D.J.; Bertness, K.A.; Kurtz, S.R.; Bode, M.; and Olson, J.M.; "Optical Detection of Band Gap Variations Due to Ordering in $\mathrm{Ga}_{0.47} \ln _{0.53}$ As on InP", Proc. Mat. Res. Soc. Symp., 1992.

15. Asher, S.; Reedy, R.C.; Swartzlander, A.B.; Schuele, P.J.; and Huffman, M.; "SIMS Analysis of Trace Element Contamination in PZT", Proc. 39th National Symposium of the American Vacuum Society, J. Vac. Sci. Technol., Chicago, IL, Nov. 9-13, 1992.

16. Asher, S.E.;, Secondary lon Mass Spectrometry, "Microanalysis of Solids", Chapter 5, B.G. Yacobi, D.B. Holt, and L.L. Kazmerski, Eds., 1993.

17. Asher, S.E.; Kalejs, J.P.; Bathey, B.; "SIMS Analysis of $\mathrm{Cr}$ Gettering in Crystalline Silicon", Proc. 11 th PV AR\&D Meeting, Denver, CO, May 13. 15, 1992. 
18. Ashour, S.; Alkuhaimi, S.; Moutinho, H.; Matson, R.; and Abou-Elfotouh, F.; "Junction Formation and Characteristics of the CdS/CulnSe $/$ Metal Interfaces", Thin Solid Films (in press), 1993.

19. Bode, M.; Ourmazd, A.; "Interfaces in GaAs/ AlAs; Perfection and Applications", J. Vac. Sci. Technol., 10, 1992.

20. Bode, M.; Al-Jassim, M.M.; Tuttle, J.; and Albin, D.; "Microcharacterization of CulnSe ${ }_{2}$ Grown by Coevaporation and Selenization", Proc. Mat. Res. Soc. Symp., 1992.

21. Bode, M.;Al-Jassim, M.M.; Jones, K.M.; Matson, R.; "Microcharacterization of Polycrystalline Semiconductor Thin Films for Photovoltaic Applications", Proc. 11th PV AR\&D Meeting, Denver, CO, May 13-15, 1992.

22. Chen, Z.; Matson, R.J.; and Burton, L.C.; "EBIC Study of Backside Hydrogen of Poly-Si Solar Cell Grain Boundaries", Physica Status Solidi A Applied Research, V 132 (1), July 16, pp. 51-58, 1992.

23. Czanderna, A.W.; "Aspects of Surface Science for the Physical Chemistry Curriculum", NREL/ TP-213-4500, December, 1991; for R. Moore and R. Schwenz, eds., Physical Chemistry, Developing a Dynamic Curriculum, ACS Books, Amer. Chem. Soc., Washington, DC, pp. 43-74, 1992.

24. Czanderna, A.W.; Landgrebe, A.R.; Eds., "Current Status, Research Needs, and Opportunities in Applications of Surface Processing to Transportation and Utilities Technologies", NREL/CP. 412-5007 [also Critical Review in Surface Chemistry, Vol. 2, No. 1, CRC Press, Inc., Boca Raton, FL, 1993 (in press)], September, 1992.

25. Czanderna, A.W.; "Overview on Surface Processing - Status and Future Directions", Proc. 14th Symposium on Applied Surface Analysis, AVS, Ann Arbor, MI, June, 1992

26. Dreszer, P.; Weber, E.R.; Khachaturyan, A.; and Matson, R.J.; "Magnetic Susceptibility of Te Donors in $\mathrm{Al}_{0.3} \mathrm{Ca}_{0.7} \mathrm{As}^{\prime}$, Proc. ICPS-21, Beijing, China, August, 1992.

27. Emery, K.; Advances in Solar Energy Vol. 7 , "Efficiency Measurements of Photovoltaic Devices", Chapter 3, Karl Böer Ed., 1992.
28. Emery, K.A.; "Efficiency Measurements on ThinFilm PV Cells and Modules", Proc. 11th Annual PV AR\&D Meeting, Golden, CO, May 13-15, 1992.

29. Emery, K.A.; "Measurement of Solar Cell Performance Parameters", Proc. 6th International Photovoltaic Science and Engineering Conf., New Delhi, India, February 10-14, pp. 793-802, 1992.

30. Emery, K.A.; Beck, E.E.; Field, H.; and Rummel, S.; "PV Performance Measurements at NREL", Proc. PV Performance and Reliability Workshop, SERI/CP-411-5184 DE93000017, Golden, CO, Sept. 16-18, 1992.

31. Emery, K.A.; and Green, M.A.; Progress in Photovoltaics Research and Applications Vol. 1 , "Solar Cell Efficiency Tables", pp. 25-29, 1993.

32. Freidman, D.J.; Kurtz, S.R.; Kibbler, A.E.;Bertness, K.A.; Kramer, C.; Matson, R.J.; Arent, D.J.; and Olsen, J.M.; "Anisotropic Electrical Transport and Surface Microstructure in GalnP ", Proc. Mat. Res. Soc. Symp. Fall, 1992.

33. Gabor, A.M.; Hermann, A.M.; Tuttle, J.R.; Albin, D.S.; Swartzlander, A.B.; and Noufi, R.; "CulnSe Thin Film Formation by Rapid Annealing of the Elemental Precursor", Proc. 11th PV AR\&D Meeting, AIP Conference Proceedings, Denver, CO, May, 1992.

34. Jones, K.M.; Hasoon, F.S.; Swartzlander, A.B.; Al-Jassim, M.M.; Chu, T.L.; and Chu, S.S.; "The Morphology and Microstructure of Polycrystalline CdTe Thin Films for Solar Cell Applications", Proc. EMSA, pp. 1384, 1992.

35. Jung, D.R.; King, D.E.; and Czanderna, A.W.;"XRay Photoelectrospectroscopy of Organized Molecular Assembly-Copper Interfaces: The OH/ Cu Interface", NREL/TP-412-5090 lalso Appl. Surf. Sci., in press. 1993], September, 1992.

36. Jung, D.R.; King, D.E.; and Czanderna, A.W.; "XPS of Organized Molecular Assembly/Copper Interfaces: $\mathrm{HS}\left(\mathrm{CH}_{2}\right)_{11} \mathrm{CN} / \mathrm{Cu}^{\prime \prime}, \mathrm{NREL} / \mathrm{TP}-412$ 5197, [also, 'J. Vac. Sci. Technol., 'Proc. 12th Intnl. Vac. Cong. (IVC-12), 3Proc. 8th Intnl. Conf. on Solid Surf. (ICSS-8), ${ }^{4} \mathrm{Appl}$. Surf. Sci. (to be published)], October, 1992. 
37. Kazmerski, L.L.; "Atomic-Level Imaging, Processing and Characterization of Defects and Surfaces Using Proximal Probe Techniques", Vacuum, 1992.

38. Kazmerski, L.L.; "Characterization of Photovoltaics: From Arrays to Atoms", Proc. 11th PV AR\&D Meeting, Denver, CO, May 13-15, 1992.

39. Kazmerski, L.L.; and Emery, K.A.; "Photovoltaic Technologies: From Atoms to Arrays", Proc. World Renewable Energy Conference, Reading, UK, September, 1992.

40. Kazmerski, L.L.; and Emery, K.A.; "Photovoltaics: Research and Technology Development"; Proc. Nordic Photovoltaic Electricity Meeting, Borlange, Norway, pp. 6-20, 1992.

41. Keyes, B.M.; "Minority-Carrier Lifetime of Compound Semiconductors in Polycrystalline CdTe", Proc. 11th PV AR\&DMeeting, Denver, CO, May 13-15, 1992.

42. Keyes, B.M.; Emery, K.A.; and Ahrenkiel, R.K.; "Minority-Carrier Lifetime of Compound Semiconductors: Polycrystalline CdTe", R. Noufi, Ed., Proc. PV Advanced Research \& Development Project, AIP Conference 268, Denver, CO, pp. 149-154, 1992.

43. King, D.E.; Czanderna, A.W.; and Spaulding, D.; "Charging Shifts During XPS Analysis of the $\mathrm{Cu} /$ Arachidic Acid Interface on Aluminum Oxide Films", J. Vac. Sci. Technol., A11(1), [also NREL TP-4120-4721], Jan/Feb, 1993.

44. King, D.E.; Czanderna, A.W.; and Spaulding, D.; "Interactions of Deposited Copper on $\mathrm{COOH}$ of 11-Mercaptoundecanoic Acid: An XPSStudy", K. Mittal, Ed., Metallized Plastics, Plenum, NY, pp. 149-161, 1992.

45. Lovejoy, M.L.; Melloch, M.R.; Lundstrom, M.S.; Keyes, B.M.; Ahrenkiel, R.K.; de Lyon, T.J.; and Woodall, J.M.; "Comparative Study of Minority Electron Properties in p+-GaAs Doped with Beryllium and Carbon", Appl. Phys. Lett., 61, pp. 822, 1992.

46. Lovejoy, M.L.; Melloch, M.R.; Ahrenkiel, R.K.; and Lundstrom, M.S.; "Measurement Considerations for Zero-Field Time-of-Flight Studies of Minority-Carrier Diffusion in III-V Semiconductors", Solid State Electronics, 35, pp. 251, 1992.
47. Lundstrom, M.S.; Melloch, M.R.; Lush, G.B.; Patkar, M.P.; Young, M.; Durbin, S.M.; Gray, J.L.; MacMillan, J.F.; Keyes, B.M.; Levi, D.H.; and Ahrenkiel, R.K.; "Radiative Recombination and Photon Recycling in GaAs Solar Cells", Proc. 11th PV AR\&D Meeting, AIP Proceedings, Golden, CO, 1992.

48. Lush, G.B.; MacMillan, H.F.; Keyes, B.M.; Lundstrom, M.S.; Ahrenkiel, R.K.; and Melloch, M.R.; "A Study of Minority-Carrier Lifetime versus Doping in $n$-Type GaAs by Metalorganic Vapor Deposition", J. Appl. Phys., 72(4), pp. 1436, 1992.

49. Lush, G.B.; Melloch, M.R.; Lundstrom, M.S.; MacMillan H.F., Keyes, B.M.; Ahrenkiel, R.K.; "Measurement of Minority Carrier Lifetimes in $\mathrm{n}$-Type GaAs and the Implications for Solar Cells", Proc. 22nd IEEE Photovoltaic Specialists Conference, pp. 182, 1991.

50. Lush, G.B.; Melloch, M.R.; Lundstrom, M.S.; Levi, D.H.; Ahrenkiel, R.K.; and MacMillan, H.F.; "Microsecond Lifetimes and Low Interface Recombination Velocities in Moderately Doped n-GaAs Thin Films", Appl. Phys. Lett., 61(20), 1992.

51. Lush, G.B.; Levi, D.H.; MacMillan, H.F.; Ahrenkiel, R.K.; Melloch, M.R.; and Lundstrom, M.S. "Microsecond Lifetimes in Moderately Doped n-GaAs Thin Films", Proc. Electronic Materials Conf., Cambridge, MA, 1992.

52. Lush, G.B.; MacMillan, H.F.; Keyes, B.M.; Ahrenkiel, R.K.; Melloch, M.R.; and Lundstrom, M.S.; "Photoluminescence Decay Study of Minority-Carrier Recombination in n-Type GaAs", Appl. Phys. Lett., (in press), 1992.

53. Margaritondo, G.;McKinley, J.T.; Rioux, D.; and Niles, D.W.; "Understanding and Controlling Semiconductor Interfaces: Spectroscopy and Spectromicroscopy", Appl. Surf. Sci., 56-58, pp. 713-722, 1992.

54. Matson, R.J.; "Recent Advances in Applications in Charge Collection Microscopy", Scanning Microscopy, Proc. 11th Pfefferkorn Conf. on the Physics of Generation and Detection of Signals Used for Microcharacterization, Univ. of Mass, August 10-14, 1992. 
55. Menezes, S.; Noufi, R.; and Matson, R.J.; "New Configuration and Method for CulnSe ${ }_{2}$-Based Thin Film Solar Cells", Proc. 11th Euorpean Communities Photovoltaic Solar Energy Conference, Montreaux, Switzerland, October 10-12, 1992.

56. Moutinho, H.R.; Ahmad-Bitar, R.; Hasoon, F.S.; Ahrenkiel, R.K.; Dunlavy, D.J.; Keyes, B.M.; Mason, A.R.; Abou-Elfotouh, F.A.; Birkmire, R.W.; and Kazmerski, L.L.; "Study of the Process Treatments Used for High-Efficiency, Thin-Film CdTe Solar Cells", Proc. 10th European Communities Photovoltaic Solar Energy Conference, Montreux, Switzerland, 1992.

57. Nann, S.; and Emery, K.; "Spectral Effects on PVDevice Ratings", Solar Energy Materials, Vol. 27, pp. 189-216, 1992.

58. Naziripour, A.; Hermann, A.M.; Swartzlander, A.B.; Nelson, A.J.; and Dong, C.; "The Influence of Processing Conditions on the Morphology and Electronic Properties of $\mathrm{Tl}-\mathrm{Ba}-\mathrm{Ca}-\mathrm{Cu}-\mathrm{O}$ (TBCCO) Superconducting Thin Films", Proc. of the Beijing International Conference on High TC Superconducting Thin Films (World Scientific, Pubs. Philadelphia, PA), 1993.

59. Nelson, A.J.; Frigo, S.; and Rosenberg, R.A.; "Photoemission Characterization of the $\mathrm{H}_{2}$ Plasma Etched Surface of CdS", J. Appl. Phys., 71(12), pp. 5881, 1992.

60. Nelson, A.J.; Niles, D.W.; Kazmerski, L.L.; Rioux, D.; Patel, R.; and Höchst, H.; "Photoemission Study on the Formation of Mo Contacts to CulnSe $_{2}{ }^{\prime \prime}$, J. Appl. Phys., 72(3), pp. 976, 1992.

61. Nelson, A.J.; Frigo, S.; and Rosenberg, R.A.; "Soft X-ray Photoemission Characterization of the $\mathrm{H}_{2} \mathrm{~S}$ Exposed Surface of p-InP", J. Appl. Phys., 71(2), pp. 6086, 1992.

62. Nelson, A.J.; Niles, D.W.; Rioux, D.; Patel, R.; and Höchst, $H_{. ;}$"Soft X-ray Photoemission Investigation on the Effect of in Doping in CdS/ CulnSe, Heterojunction Formation", J. Appl. Phys. 72(12), pp. 5888, 1992.

63. Nelson, A.j.; Niles, D.W.; Kazmerski, L.L.; Rioux, D.; Patel, R.; and Höchst, H.; "The Effect of In Doping in CdS/CulnSe ${ }_{2}$ Heterojunction Formation: APhotoemission Investigation", Proc. 11th PV AR\&D Meeting, AIP Conference Proceedings, No. 268, Denver, CO, pp. 228, 1992.
64. Nelson, A.J.; "The $\mathrm{H}_{2} \mathrm{~S}$ Plasma Exposed Surface of InP: A Photoemission Investigation", Proc. 39th National Symposium of the American Vacuum Society, Chicago, IL, Nov. 9-13, J. Vac. Sci. Technol., A11 (4), 1993.

65. Nelson, A.J.; Schwerdtfeger, C.R.; Wei, S-H; Zunger, A.; Rioux, D.; Patel, R.; and Höchst, $H_{\text {.; }}$ "Theoretical and Experimental Studies of the $\mathrm{ZnSe} / \mathrm{CulnSe}$, Heterojunction Band Offset", Appl. Phys. Lett. 61(12), 1993.

66. Niles, D.W.; Rioux, D.; and Höchst, H.; "A Photoemission Investigation of the $\mathrm{SnO}_{2} / \mathrm{CdS}$ Interface: A Front Contact Interface Study of CdS/CdTe Solar Cells", J. Appl. Phys. 1993.

67. Niles, D.W.; "Band Offsets and Strain Relaxation in $\mathrm{ZnTe} / \mathrm{CdTe}(100)$ Heterostructures", Proc. 39th National Symposium of the Anierican Vacuum Society, J. Vac. Sci. Technol., Chicago, IL, Nov. 9-13, 1992.

68. Niles, D.W.; Nelson, A.J.; Schwerdtfeger, C.R., Höchst, H.; and Rioux, D.; "Mo and Ni Schottky Barriers to CulnSe ${ }_{2}(112)^{\prime \prime}$, Proc. Mat. Res. Soc. Symp., No. 260, Advanced Metallization and Processing for Semiconductor Devices and Circuits-II, pp. 299, 1992.

69. Niles, D.W.; Höchst, H.; and Rioux, D.; "Polarization Selection Rules in Photoemission from Valence Bands of Zinc Blende Semiconductors", Phys. Rev. B, pp. 12547, 1992.

70. Niles, D.W.; Höchst, H.; and Rioux, D.; "Valence Band Discontinuity at the $\mathrm{ZnTe} / \mathrm{CdTe}$ Interface: Making Ohmic Contact to p-Type CdTe", AIP Conference Proceedings 268, R. Noufi, Ed., pp. 279, 1992.

71. Niles, D.W.; and Höchst, H.; "Determination of the Bowing Parameter of the Split-Off Band in $\mathrm{Cd}_{0.8} \mathrm{Zn}_{0.2} \mathrm{Te}(100)$ by Angle Resolved Photoemission Spectroscopy", Phys. Rev. B 46, pp. 1498, 1992.

72. Niles, D.W.; and Margaritondo, G.; "Electronic Properties of Semiconductor-Semiconductor Interfaces and Their Control Using Interface Chemistry", Atomic-Level Properties of Interface Materials, S. Yip and D. Wolf, Eds. (Chapman and Hall, London), pp. 592, 1992. 
73. Niles, D.W.; and Höchst, H.; "Manifestation of Electric Dipole Selection Rules in Angle Resolved Photoemisison Spectra from Zinc Bland Semiconductors", J. Vac. Sci. Technol., A10(4), pp. 1526, 1992.

74. Osterwald, C.R.; "Photovoltaic Standards Development Within ASTM" $^{\prime \prime}$, Proc. 11 th PV AR\&D Meeting, Denver, CO, May, 1992.

75. Osterwald, C.R.; and Dippo, P.C.; Eds., "FY 1991 Measurements and Characterization Branch Annual Report", NREL/TP-412-5160, November, 1992.

76. Paranthaman, M.; Foldeaki, M.; Balzar, D.; Ledbetter, H.; Nelson, A.J.; and Hermann, A.M.; "Enhanced Flux Pinning via Chemical Substitution in Bulk TI-2212", Phys. Rev. B (Submitted), 1992.

77. Pern, F.J.; "A Comparative Study of Solar Cell Performance Under Thermal and Photothermal Tests", Proc. PV Performance \& Reliability Workshop, NREL/CP-411-5184, Golden, CO, pp. 327 . 344, 1992.

78. Pern, F.J.; "Luminescence and Absorption Characterization of Ethylene-Vinyl-Acetate Encapsulant for PV Modules Before and After Weathering Degradation", NREL/TP-213-4605 Revised, Polymer Degradation and Stability, August, 1992.

79. Pern, F.J.; and Czanderna, A.W.; "Characterization of Ethylene Vinyl Acetate (EVA) Encapsulant: Effects of Thermal Processing and Weathering Degradation of its Discoloration", Solar Energy Materials and Solar Cells, 25, pp. 3-23, 1992.

80. Pern, F.J.; and Czanderna, A.W.; "Investigation of EVA Degradation Mechanisms", Proc. 11th PV AR\&D Meeting, Denver, CO, May 13-15, 1992.

81. Pern, F.J.; and Czanderna, A.W.; "Spectroscopic Studies of Degradation of Ethylene Vinyl Acetate (EVA) Copolymer Encapsulant for PV Modules", Proc. 34th Rocky Mountain Conference on Analytical Chemistry, No 186, [also NREL/TP-4124786], Denver, CO, July 28-August 3, 1992.
82. Pern, J.; and Czanderna, A.W.; "EVA Degradation Mechanisms Simulating Those in PV Modules", Proc. 11th PVAR\&D, (also NIREL/TP-4124940], Denver, CO, May, 1992.

83. Perry, A.J.; Sartwell, B.D.; Valvoda, F.; Rafaja, D.; Williamson, D.L.; and Nelson, A.J.; "Residual Stress and the Effect of Implanted Argon in Films of Zirconium Nitride Made by Physical Vapor Deposition", J. Vac. Sci. Technol.,A10(4), pp. 1446, 1992.

84. Pesaran, A.A.; Penney, T.R.; and Czanderna, A.W.; "Desiccant Cooling: State-of-the-Art Assessment", NREL/TP-254-4147, October, 1992.

85. Pitts, J.R.; Tracy, E.; and Shinton, Y.; "Applications of Solar Energy to Surface Modification Processes", Proc. DOE Sunrace Processing Workshop, NREL/CP-412-5007, A.R. Landgrebe and A.W. Czanderna, Eds., Boca Raton, FL, Dec. 10-12, 1992.

86. Pitts, J.R.; Tracy, E.; Shinton, E.; and Fields, C.L.; "Surface Modification Using Concentrated Solar Radiation", Proc. 1992 ASME/JSES/KSES Int. Solar Energy Conf., ASME New York, Maui, Hawaii, April 4-8, pp. 1107-1112, 1992.

87. Pugh, J.R.; Mao, D.; Zhang, J-G; Heben, M.J.; Nelson, A.J.; and Frank, A.J.; "A Metal:p-n-CdTe Schottky-Barrier Solar Cell; Photo-electrochemical Generation of a Shallow p-Type Region in n.CdTe", J. Appl. Phys., 73 (in press), 1993.

88. Rocheleau, R.E.; Zhang, J.; Niles, D.W.; and Mason, A.; "Effect of Hydrogen Dilution on the Properties and Bonding in Plasma-Deposited Silicon Nitride", J. Appl. Phys., July, 1992.

89. Rohde, S.L.; Nelson, A.J.; Mason, A.; and Sproul, W.D.; "Characterization of TiN Films Deposited Using Multi-Cathode Unbalanced Magnetrons", J. Vac. Sci. Technol., A10(4), pp. 1797, 1992.

90. Rosenwaks, Y.; Thacker, B.R.; Ahrenkiel, R.K.; and Nozik, A.J.; "Electron Transfer Dynamics at p-GaAs Liquid Interfaces", J. Phys. Chem. (in press), 1993.

91. Rosenwaks, Y.; Hanna, N' C.; Levi, D.H.;Szmyd, D.M.; Ahrenkiel, R.K.; and Nozik, A.J.; "Hot Carrier Cooling in GaAs: Quantum Wells vs Bulk", Phys. Rev. B15, 1993. 
92. Sheldon, P.; Keyes, B.M.; Ahrenkiel, R.K.; and Ash ar S.E.; "Minority Carrier Lifetimes in MBEGrown $\mathrm{Al}_{\mathrm{x}} \mathrm{Ga}_{1-\mathrm{A}} \mathrm{As} / \mathrm{GaAs}$ Double Heterostructures Doped With Aluminum", J. Vac. Sci. Technol. (in press), 1993.

93. Sopori, B.L.; Jones, K.M.; and Deng, X.J.; "Observations of Enhanced Hydrogen Diffusion in Solar Cell Si", Appl. Phys. Lett., 61, pp. 2560, 1992.

94. Tuttle, J.R.; Contreras, M.; Matson, R.J.; Bode, M.; Nelson, A.J.; Albin, D.S.; and Noufi, R.; "Growth Mechanisms, Characterization, and Device Performance of Thin-Film Cu(In,Ga)Se Fabricated by a Novel Two-Stage Process", Proc. Mat. Res. Soc. Symp. Spring, II-VI Compound Semiconductor Photovoltaic Technology, San Francisco, CA, 1993.

95. Tuttle, J.R.; Contreras, M.; Tennant, A.; Matson, R.; Duda, A.; Carapella, J.; Albin, D.; and Noufi, R.; "Novel Processing and Device Structures in Thin-Film CulnSe ${ }_{2}$-Based Solar Cells", Proc. 11 th PV AR\&D Meeting, AIP Proceedings, Denver, CO, May 13-15, 1992.

96. Tycko, R; Dabbagh, G.; Kurtz, S.R.; and Goral, J.P.; "Quantitative Study of Atomic Ordering in GalnP by 31P Nuclear Magnetic Resonance", Phys. Rev. B 45, pp. 13452, 1992.

97. Uchida, H.; Curtis, C.J.; Prashant, P.V.; Kamat, V.; Jones, K.M.; and Nozik, A.J.; "Optical Properties of GaAs Nanocrystals", J. Phys. Chem., 96, pp. 1156, 1992.

98. Venkatasubramanian, R.; Posthill, J.B.; Timmons, M.L.; Ehsani, H.; Ghandhi, S.K.; Keyes, B.M.; and Ahrenkiel, R.K.; "Aspects of High MinorityCarrier Lifetime GaAs on Si Using a Novel SiGe/ Ge Buffer", Appl. Phys. Lett., 60, pp. 886, 1992.

99. Webb, J.D.; and Johnson, E.J.; "FTIR Analysis of Contaminated Bondlines", Proc. Joint ArmyNavy-Air Force Non-Destructive Analysis Subcommittee (ANNAF/ NDES), Seattle, Washington, July, 1992.

100. Zhang, J.; Sheldon, P.; and Ahrenkiel, R.K.; "A GaAs Hall Probe for Characterizing High Temperature Superconductors", J. Appl. Phys., 63, pp. 2259, 1992.
101. Zhu, J.G.; Al-Jassim, M.M.; Karam, N.H.; and Jones, K.M.; "Defect Reduction in GaAs Grown on Si by Using Saw-Tooth-Patterned Substrates", Proc. Mat. Res. Soc., Fall Meeting, Boston, Mass, November, 1992. 


\section{STAFF BIOGRAPHIES}

Fouad Abou-Elfotouh (NREL 1986): Senior Scientist. Research and support interests and responsibilities: electro-optical properties (including defect states and their behavior) of semiconductor (thin films and single crystals); fabrication, characterization, and modeling of heterojunction devices, solar cell back contacts; and development of spectroscopic ellipsometer.

Richard K. Ahrenkiel (NREL 1981): Principal Scientist and Group Leader. Research and support interests and responsibilities: materials characterization by photoluminescence and diffusion measurements; deep-leveltransient-spectroscopy; $\mathrm{C}-\mathrm{V}$ measurements; and superconductor characterization.

MowafakM. Al-Jassim(NREL 1983): Senior Scientist and Group Leader, Materials Science. Research and support interests and responsibilities: transmission electron microscopy (TEM); scanning electron microscopy (SEM); defect analysis in semiconductors, and epitaxial growth by MOCVD and MBE.

Sarah (Sally) Asher (NREL 1985): Senior Scientist, Analytical Chemistry. Research and support interests and responsibilities: surface science; operation and maintenance of SIMS facility.

Elvira Beck (NREL 1987): Master Technician. Research and support interests and responsibilities: PV cell measurements and characterization by area, spectral response; and quantum efficiency; intensity, current vs. voltage, and reference cell calibrations.

Michael H. Bode (NREL 1992): Senior Scientist. Research interests and responsibilities: transmission electron microscopy (TEM); scanning electron microscopy (SEM); structural, electrical and optical characterization of semiconductors; semiconductor interface analysis.

Alvin W. Czanderna (NREL 1978): Research Fellow and Group Leader. Research and support interests and responsibilities: surface science; reactions at interfaces; stability and durability of multilayer thin-film devices; interactions at polymer/metal (oxide) interfaces; surface analysis; ultramicrogravimetry.

Patricia C. Dippo (NREL 1980): Administrative Assistant. Research and support interests and responsibilities: supports five of the groups within the branch and prepares branch correspondence; reports; etc.; organizes day-today branch operations.
Donald J. Dunlavy (NREL 1981): Staff Scientist. Research and support interests and responsibilities: minority carrier characterization by photoluminescence and diffusion measurements; design, modification; and maintenance of all test equipment.

Keith A. Emery (NREL 1980): Senior Scientist and Croup Leader. Research and support interests and responsibilities: PV performance characterization by current versus voltage, temperature; spectrum, and intensity; PV calibration; quantum efticiency; PV standards.

Halden Field (NREL 1992): Associate Scientist. Research and support interests and responsibilities: solar cell performance and characterization equipment, software, and methods, including current vs. voltage, spectral response, and calibrations.

Clark L. Fields (NREL 1990) Visiting Professional (Summer), Prof. of Chemistry at the University of Northern Colorado, Greeley. Research and support interests and responsibilities: rapid thermal processing of materials; metal/organic chemistry; boron chemistry; chemical vapor deposition; ceramic superconductors.

Amy B. Swartzlander-Franz (NREL 1980): Associate Scientist. Research and support interests and responsibilities: characterization of solar and electronic devices, including superconductors, using SAM; AES, and XPS.

Falah Hasoon (NREL 1990): Visiting Professional. Research and support interests and responsibilities: scanning electron microscopy; luminescent properties, and defect examination in semiconductors.

Greg Herdt (NREL 1991): Research Associate. Research and support interest and responsibilities: applied surface science; sorption phenomena of desiccant materials using microgravimetric and flow techniques; computerized evaluation and modeling of sorption processes.

Kim M. Jones (NREL 1981): Staff Scientist. Research and support interests and responsibilities: transmission electron microscopy; analytical electron microscopy; defect analysis in semiconductors.

David Jung (NREL: 1992): Postdoctoral Research Associate, Research and support interests and responsibilities: Metal/organic interface interactions of deposited metals on organized molecular assemblies using XPS, contact angle. and STM. 
Elizabeth (Jo) Johnson (NREL 1990): AWU Student Fellow. Research and support interests and responsibilities: Fourier transform infrared (FTIR) spectroscopy and analysis.

Lawrence L. Kazmerski (NREL 1977): Principal Scientist and Branch Manager. Research and support interests and responsibilities: scanning tunneling microscopy; surface and interface analysis research.

Brian M. Keyes (NREL 1988): Associate Engineer. Research and support interests and responsibilities: minority-carrier characterization by photoluminescence and diffusion measurements; modeling of the above measurements; computer analysis and interfacing.

David King (NREL 1989): Staff Analytical Chemist. Research and support interests and responsibilities: surface analysis; FTIR spectroscopy; thin films and interfaces.

Dean Levi (NREL 1990): Research Associate. Research and support interests and resfonsibilities: time-resolved photoluminescence measurements of minority carrier lifetime; photon recycling; surface recombination velocity; chemical passivation of surface defects. Also extending laboratory capabilities through development of new measurement techniques.

Alice Mason (NREL 1984): Master Technician. Research and support interests and responsibilities: sample preparation for microscopy examination.

Richard Matson (NREL 1979): Staff Scientist. Research and support interests and responsibilities: scanning electron microscopy; $X$-ray microanalysis; defect examination in semiconductors and luminescent properties.

Helio Moutinho (NREL 1991): Research Associate. Research and support interests and responsibilities: materials characterization by scanning tunneling microscopy.

Art J. Nelson (NREL. 1985): Senior Scientist and Group Leader. Research and support interests and responsibilities: surface and interface analysis research; surface and grain boundary phenomena in semiconducting and superconducting materials; synchrotron radiation photoemission on crystalline; polycrystalline, and amorphous materials; growth and characterization of $11-\mathrm{VI}$ semiconductors; plasma modification of surfaces.

David W. Niles (NREL 1991): Staff Scientist. Research and support interests and responsibilities: characterization of PV materials; devices and modules; surface and interface phenomena; measurement-system development.
Carl Osterwald (NREL 1982): Staff Scientist. Research and support interests and responsibilities: measurement system design and development; primary PV reference cell calibration; spectral response; current versus voltage measurements.

F.J. Pern (NREL 1984): Senior Scientist. Research and support interests and responsibilities: material fabrication and characterization; spectral, analytical, and electrochemical characterization of PV encapsulant polymers, metalization, and other module materials; module performance testing and analysis of failure mechanisms.

J. Roland Pitts (NREL 1979) Senior Physicist. Research and support interest and responsibilities: surface modification using particle beams; surface and interface science; stimulated desorption; transient thermal processes; optical and physical properties of thin films.

Robert Reedy (NREL 1992): Staff Scientist. Research and support interests and resonsibilities: Materials $c$, raracterization by secondary ion mass spectrometry; surface and interface analysis, trace element analysis, equipment maintenance and repair.

John D. Webb (NREL 1978): Senior Chemist and Center Manager. Research and support interests and responsibilities: Fourier Transform Infrared (FTIR) spectroscopy; poiymer chemistry; photochemistry; and operation, maintenance, and business development for the FTIR Spectroscopic Research and Service Center.

Regina Witherspoon (NREL, 1990): Administrative Assistant. Research and support interests and responsibilities: supports Materials Durability and Component Reliability Group and the Surface Interactions Modifications, and Stability Group by the preparation of correspondence, reports, etc.; day-to-day group operations.

Jue Zhang (NREL, 1990): Research Associate. Research and support interests and responsibilities: deep-leveltransient spectroscopy.

Jane Zhu (NREL, 1991): Research Associate. Research and support interests and responsibilities: materials science: transmission electron microscopy; structure and properties of materials, defects, and interfaces in heterostructures. 


\section{COOPERATIVE LABORATORIES}

\author{
Advanced Photovoltaic Systems \\ Ain Shams University, Egypt \\ Airtech Corporation \\ Alpha Solarco \\ Alabama Power Company \\ Argonne National Laboratory \\ Arizona State University \\ Armco Research and Technology \\ Applied Solar Energy Corporation \\ AstroPower, Inc. \\ AT\&T Bell Laboratories \\ Ben Gurion University, Israel \\ $\mathrm{BHEL}$, India \\ Boeing Aerospace Company \\ Brooklyn Polytechnic Institute \\ Brookhaven National Laboratories \\ Brown University \\ California Institute of Technology \\ Cargocaire Engineering, Inc. \\ Carnegie-Mellon University \\ Chronar Corporation \\ Colorado School of Mines \\ Colorado State University \\ Coors Ceramic \\ Cornell University \\ Crystal Systems, Inc. \\ Duke University \\ Eaton Corporation \\ EIC Laboratories \\ Electrotechnica! Laboratory, Japan \\ ENEA, Italy \\ Energy Conversion Devices \\ ENTECH, Inc. \\ Electric Power Research Institute \\ EXXON Research \\ Florida Solar Energy Center \\ Ford Aerospace \\ Franhofer Institute for Solar Energy Germany \\ Fuji Electric, Japan \\ Georgia Institute of Technology \\ Georgia Tech Research Institute \\ Glasstech Solar \\ Golden Photon \\ Grumman Aerospace Corporation \\ GTE Laboratories \\ Harvard University \\ Howard University \\ Hughes Research Laboratories \\ IBM \\ Indian Institute of Technology, Delhi
}

Institute of Energy Conversion

Institute for Non-Ferrous Metals, Beijing, China

Instituto Militar de Engenharia, Brazil

International Energy Foundation

International Solar Electric Technologies

lowa State University

Jet Propulsion Laboratory

King Abdul-Aziz University, Saudi Arabia

Kyocera

Kopin Corporation

Lawrence Berkeley Laboratories

Louisiana State University

Mankato State University

Man-Tech Development, Inc.

Martin Marietta

Massachusetts Institute of Technology

Materials Research Group

Matsushita, Japan

MIT Lincoln Laboratory

Mobil Solar Energy Corporation

Montana State University

Motorola

NASA Lewis Research Center

National Institute for Silicon Technology, Pakistan

National Physical Laboratory, New Delhi, India

National Institute for Standards and Technology

Naval Research Laboratories

NESTE, France

Newcastle-Upon-Tyne Polytechnic, England

Nippon Telegraph \& Telephone, Japan

North Carolina State University

Oak Ridge National Laboratory

Oregon State University

Osaka University, Japan

Pacific Gas and Electric

Pennsylvania State University

Photocomm

Photon Energy, Inc.

Princeton University

PTB, Braumschweig, Germany

Purdue University

Reed College

Rensselaer Polytechnic Institute

Research Triangle Institute

Sandia National Laboratories

Santa Barbara Research Center

Sanyo, Japan

Science Applications International Corporation

Shanghai Institute of Metallurgy, China

Siemens Solar Industries

State University of New York

Solar Cells, Inc.

Solarex Corporation

Solec International, Inc.

Solens, France 
Spectrolab

Spire Corporation

Stanford University

Syracuse University

Texas Instruments, Inc.

Tideland Signal, Inc.

University of Colorado

University of Delaware

University of Florida

University of Illinois

University of New South Wales

University of North Carolina

University of Oregon

University of Sao Paulo, Brazil

University of Southern California

University of South Florida

University of Texas

University of Toledo

University of Utah

University of Washington

University of Wisconsin

United Solar Systems Corporation

Utility Power Group

Varian Associates

Washington State University

Weizmann Institute of Science, Israel

Westinghouse Electric Corporation

Wind Boron

Wuhan University, China

Xerox PARC 


\begin{tabular}{|c|c|c|c|}
\hline $\begin{array}{c}\text { Document Control } \\
\text { Page }\end{array}$ & $\begin{array}{l}\text { 1. NREL Report No. } \\
\text { NREL/TP-412-5422 }\end{array}$ & $\begin{array}{l}\text { 2. NTIS Accession No. } \\
\text { DE93000094 }\end{array}$ & 3. Recipient's Accession No. \\
\hline \multirow{2}{*}{\multicolumn{3}{|c|}{$\begin{array}{l}\text { 4. Title and Subtitle } \\
\text { FY } 1992 \text { Measurements and Characterization Branch Annual Report }\end{array}$}} & $\begin{array}{l}\text { 5. Publication Date } \\
\text { March } 1993\end{array}$ \\
\hline & & & 6. \\
\hline $\begin{array}{l}\text { 7. Author(s) } \\
\text { P.C. Dippo, Editor }\end{array}$ & & & 8. Performing Organization Rept. No. \\
\hline \multirow{2}{*}{\multicolumn{3}{|c|}{$\begin{array}{l}\text { 9. Performing Organization Name and Address } \\
\text { National Renewable Energy Laboratory } \\
1617 \text { Cole Blvd. } \\
\text { Goiden, CO } 80401\end{array}$}} & $\begin{array}{l}\text { 10. Project/TaskWork Unit No. } \\
\text { PV312001 }\end{array}$ \\
\hline & & & $\begin{array}{l}\text { 11. Contract (C) or Grant (G) No. } \\
\text { (C) } \\
\text { (G) }\end{array}$ \\
\hline \multirow{2}{*}{\multicolumn{3}{|c|}{$\begin{array}{l}\text { 12. Sponsoring Organization Name and Address } \\
\text { National Renewable Energy Laboratory } \\
1617 \text { Cole Blvd. } \\
\text { Golden, CO } 80401-3393\end{array}$}} & $\begin{array}{l}\text { 13. Type of Report \& Period Covered } \\
\text { Technical Report } \\
\text { I February 1992-31 January } 1993\end{array}$ \\
\hline & & & 14. \\
\hline \multicolumn{4}{|c|}{$\begin{array}{l}\text { 15. Supplementary Notes } \\
\text { NREL technical monitor: None. }\end{array}$} \\
\hline \multicolumn{4}{|c|}{$\begin{array}{l}\text { This report describes work done by the Measurements and Characterization Branch of the National Renewable Energy } \\
\text { Laboratory (NREL) during FY } 1992 \text { to provide comprehensive photovoltaic (PV) materials, devices, characterization, } \\
\text { measurement, fabrication, modeling research, and support for the international PV research community, in the context of the } \\
\text { U.S. Department of Energy's Photovoltaic Research Program goals. This report summarizes the progress of the branch from } \\
\text { 1 February } 1992 \text { through } 31 \text { January } 1993 \text {. The eight technical sections present a succinct overview of the capabilities and } \\
\text { accomplishments of each group in the branch. The branch is comprised of the following groups: Surface and Interface } \\
\text { Analysis; Materials Characterization; Device Development; Electro-optical Characterization; Advanced PV Module } \\
\text { Performance and Reliability Research; Cell Performance Characterization; Surface Interactions, Modification, and Stability; } \\
\text { and FTIR Spectroscopic Research. }\end{array}$} \\
\hline \multicolumn{4}{|c|}{$\begin{array}{l}\text { 17. Document Analysis } \\
\text { a. Descriptors } \\
\text { measurements ; characterization ; devices ; materials ; fabrication ; modeling ; phowvoltaics ; solar cells } \\
\text { b. Identifiers/Open-Ended Terms }\end{array}$} \\
\hline \multirow{2}{*}{\multicolumn{2}{|c|}{$\begin{array}{l}\text { 18. Availability Statement } \\
\text { National Technical Information Service } \\
\text { U.S. Department of Commerce } \\
5285 \text { Port Royal Road } \\
\text { Springfield, VA } 22161\end{array}$}} & & \begin{tabular}{|c|} 
19. No. of Pages \\
31 \\
\end{tabular} \\
\hline & & & $\begin{array}{l}\text { 20. Price } \\
\mathrm{A} 03\end{array}$ \\
\hline
\end{tabular}

Form No. 0069E (6-30-87) 

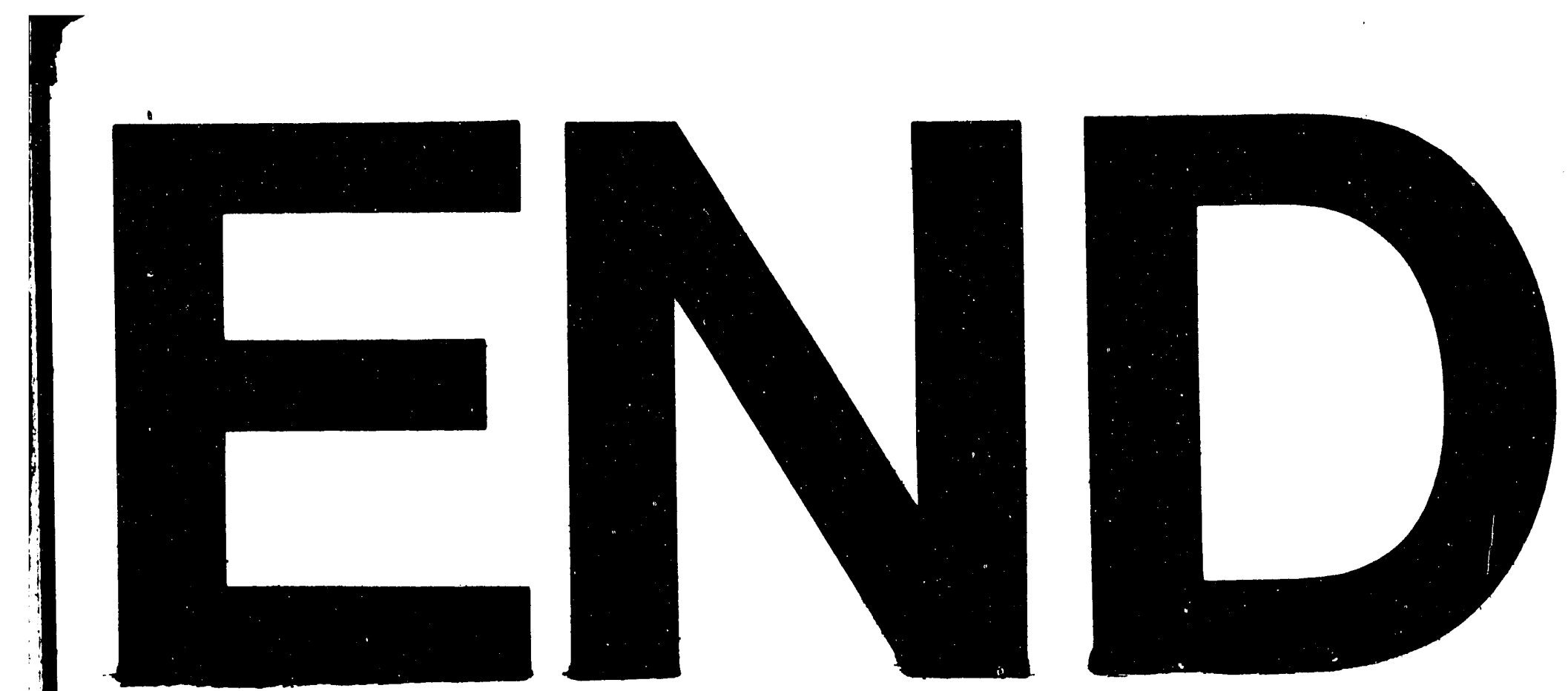

$x$
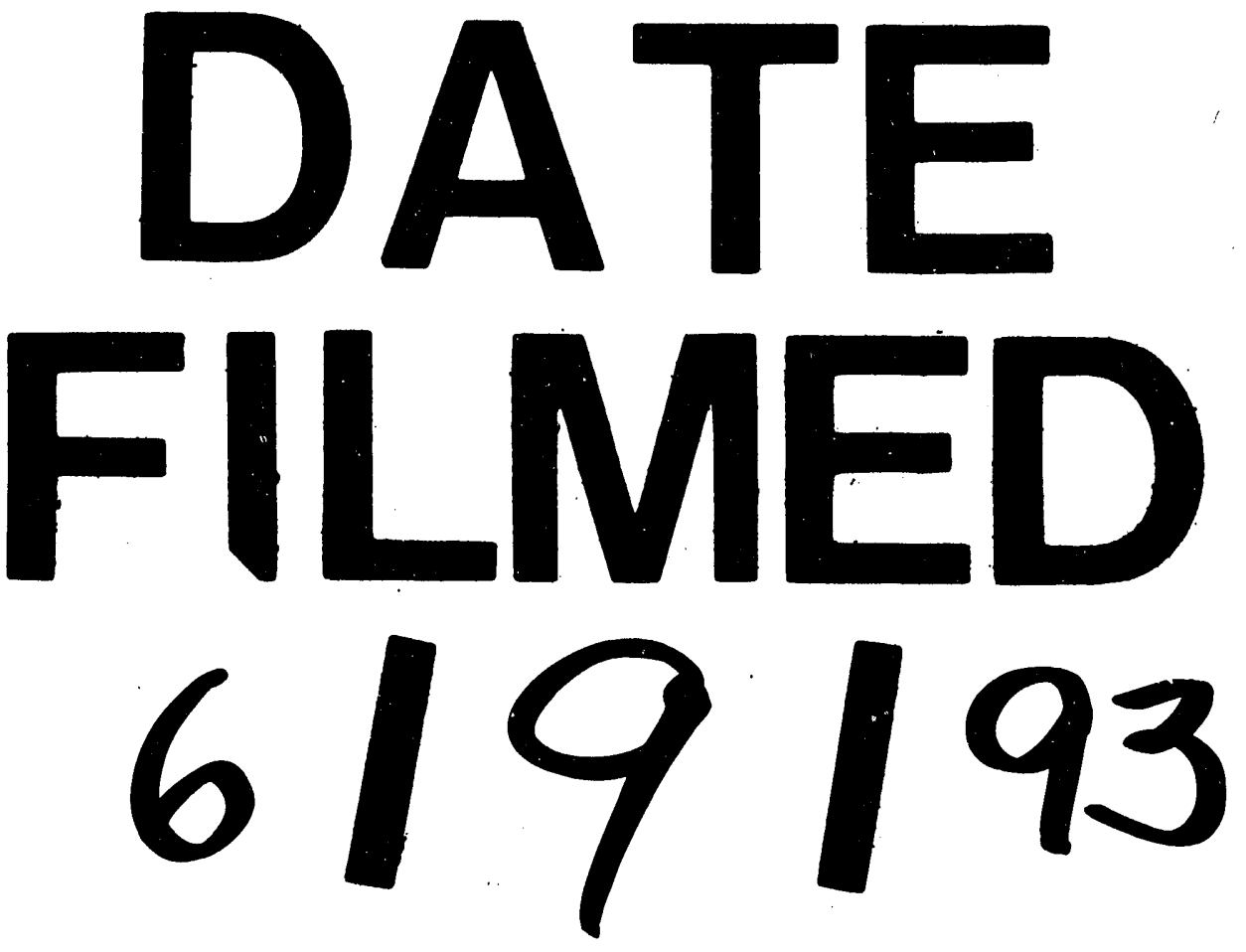
